\title{
Vanadium-Lithium Alkoxides: Synthesis, Structure, Spectroscopic Characterisation and Accidental Degradation of Silicone Grease
}

\author{
Dayane M. Reis, ${ }^{a}$ Kátia Cristina M. Westrup, ${ }^{a}$ Giovana G. Nunes, ${ }^{a}$ Andersson Barison, ${ }^{a}$ \\ Ronny R. Ribeiro, ${ }^{a}$ Eduardo L. de Sá, ${ }^{a}$ David L. Hughes ${ }^{b}$ and Jaísa F. Soares ${ }^{*, a}$
}

\author{
${ }^{a}$ Departamento de Química, Universidade Federal do Paraná, Centro Politécnico, 81530-900, Curitiba-PR, Brazil \\ ${ }^{b}$ School of Chemical Sciences \& Pharmacy, University of East Anglia, Norwich NR4 7TJ, UK
}

Dois complexos contendo vanádio e lítio, $\left[\mathrm{V}_{6} \mathrm{Li}_{10} \mathrm{O}_{8}(\mathrm{ONep})_{14}\left\{\mathrm{OSi}(\mathrm{Me})_{2}(\mathrm{ONep})\right\}_{2}\right](\mathbf{1})$ e $\left[\mathrm{V}(\mathrm{ONep})_{3}(\boldsymbol{\mu} \text {-ONep })_{2} \mathrm{Li}(\mathrm{thf})_{2}\right](\mathbf{2}), \mathrm{Nep}=$ neopentila, $\mathrm{Me}=$ metila e thf $=$ tetraidrofurano, foram isolados em alto rendimento e caracterizados por diversas técnicas incluindo espectroscopias de ressonância paramagnética eletrônica (RPE, banda X) e ressonância magnética nuclear (RMN) de ${ }^{29} \mathrm{Si}$, medidas de susceptibilidade magnética e difratometria de raios $\mathrm{X}$ de monocristal. A despeito das condições similares de preparação, os dois produtos apresentam características estruturais admiravelmente distintivas: o complexo binuclear não-oxo 2 é um simples produto de adição de "V(ONep) $)_{4}$ " e "Li(ONep)(thf) ${ }_{2}$ ", enquanto 1 é um agregado de valência mista com 16 centros metálicos. O oxoalcóxido molecular 1 também contém grupos silanolatos, $\left\{\mathrm{OSi}\left(\mathrm{Me}_{2}\right)(\mathrm{ONep})\right\}^{-}$, produzidos por ataque nucleofílico de neopentóxidos à graxa de silicone dissolvida acidentalmente no meio de reação. Ambos os produtos têm aplicações promissoras em síntese orgânica e inorgânica, incluindo a preparação de óxidos mistos pouco comuns contendo vanádio, lítio e/ou silício.

Two complexes containing both vanadium and lithium, $\left[\mathrm{V}_{6} \mathrm{Li}_{10} \mathrm{O}_{8}(\mathrm{ONep})_{14}\left\{\mathrm{OSi}(\mathrm{Me})_{2}\right.\right.$ $\left.(\mathrm{ONep})\}_{2}\right](\mathbf{1})$ and $\left[\mathrm{V}(\mathrm{ONep})_{3}(\mu-\mathrm{ONep})_{2} \mathrm{Li}(\mathrm{thf})_{2}\right](\mathbf{2}), \mathrm{Nep}=$ neopentyl, Me = methyl and thf $=$ tetrahydrofuran, have been isolated in high yield and characterised by a number of techniques including X-band electron paramagnetic resonance (EPR) and ${ }^{29} \mathrm{Si}\left\{{ }^{1} \mathrm{H}\right\}$ nuclear magnetic resonance (NMR) spectroscopies, magnetic susceptibility measurements and single crystal X-ray diffractometry. Despite the similar preparation conditions, the two products present remarkably

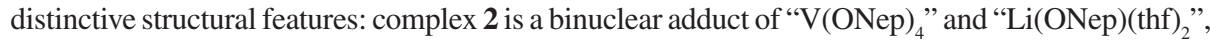
while $\mathbf{1}$ is a mixed-valence, 16-metal aggregate. The large molecular oxoalkoxide $\mathbf{1}$ also contains silanolate units, $\left\{\mathrm{OSi}\left(\mathrm{Me}_{2}\right)(\mathrm{ONep})\right\}^{-}$, produced by nucleophilic attack of neopentoxide groups on $\mathrm{Si}-\mathrm{O}$ bonds of silicone grease accidentally dissolved in the reaction media. Both products have promising applications in organic and inorganic synthesis, including the preparation of uncommon $\mathrm{V}-\mathrm{Li}$ and/or Si containing oxides.

Keywords: vanadium(IV), lithium, alkoxide, silicone grease, neopentoxide

\section{Introduction}

The literature on vanadium alkoxide chemistry describes a number of high valence, vanadium(V) compounds prepared from commercially available $\mathrm{VOCl}_{3}, \mathrm{~V}_{2} \mathrm{O}_{5}$, $\left(\mathrm{NH}_{4}\right) \mathrm{VO}_{3}$ or $\mathrm{VO}(\mathrm{OR})_{3}(\mathrm{R}=$ alkyl $)$. These species have received attention because of their applications as catalysts in polymerization reactions ${ }^{1}$ and as precursors of industrially applied homo- and mixed-metal oxides. ${ }^{2}$ There is also an increasing interest on the preparation of lower oxidation

*e-mail: jaisa@quimica.ufpr.br state vanadium alkoxides, such as non-oxo vanadium(III)/ (IV) compounds, to be employed as direct precursors of less common oxides without the use of reducing reaction conditions. ${ }^{3}$ However, these syntheses have been hampered by the lack of suitable non-oxo starting materials, as the very stable vanadyl(IV)/(V)-containing precursors which are commercially available have a different reactivity pattern when compared to non-oxo compounds. ${ }^{4}$

Most vanadium(III)/(IV) alkoxides reported to date are homonuclear compounds with chelating or bulky ligands that help avoiding oligomerization. ${ }^{5}$ In our work, we have employed less hindered alkyls, such as isopropyl ( $\left.\operatorname{Pr}^{\mathrm{i}}\right)$ and 
neopentyl (Nep) groups, to develop new starting materials, in analogy to those described for titanium(IV). ${ }^{6}$ Although the preparation of the first non-oxo vanadium(IV) alkoxides was reported as early as in the $1950 \mathrm{~s},{ }^{7}$ the reactivity and the structural patterns of these compounds are not well established and it was only recently that $\left\{\mathrm{V}(\mathrm{OR})_{4}\right\}_{\mathrm{n}}$ species was used in the preparation of mixed-metal aggregates. ${ }^{8}$

The synthesis of heterometal alkoxo species is highly dependent upon the tendency of alkoxides or other ligands, such as halides, to bridge. ${ }^{9}$ In addition, some of the known complexes spontaneously dissociate in solution or under thermal treatment. As an example, Albaric et al. ${ }^{10}$ reported dissociative behaviour in solution for both homo and heterometal species when trying to isolate $\mathrm{V} / \mathrm{Mg}$ alkoxides. Similar observations have also been made by our research group for $\left[\mathrm{V}_{2}\left(\mu-\mathrm{OPr}^{\mathrm{i}}\right)_{2}\left(\mathrm{OPr}^{\mathrm{i}}\right)_{6}\right]^{11}$ and $\left[\mathrm{FeI}_{2}\left(\mu-\mathrm{OPr}^{\mathrm{i}}\right)_{2} \mathrm{~V}\left(\mathrm{OPr}^{\mathrm{i}}\right)_{2}\left(\mathrm{Pr}^{\mathrm{i} O H}\right)\right]^{8}$ the isolation of the latter being highly dependent on the composition of the crystallization mixture.

Our present interest in vanadium and lithium alkoxides of the "LiV(OR)" type is based on their potential use as starting materials for the metathetical synthesis of heterometal aggregates with other transition metals, ${ }^{11}$ which, in their turn, are attractive precursors of industrially applied mixed metal oxides. " "LiV(OR) 5 "-type materials can also be employed in the preparation of lithium-intercalated layered vanadium oxide films for electrochemical applications. ${ }^{13}$ For this purpose, the lithium ion is considered an ideal guest cation, because it readily intercalates without significant alteration of the host crystal structure.

This work describes the facile 1:1 reaction between "Li(ONep)" ${ }^{\prime \prime}$ and $\left[\mathrm{V}_{2}(\mu \text {-ONep })_{2}(\mathrm{ONep})_{6}\right]$ (Figure 1). ${ }^{15}$ The system has shown high reactivity towards the silicone grease used in ground glass joints, and two very different products were isolated, $\left[\mathrm{V}_{6} \mathrm{Li}_{10} \mathrm{O}_{8}(\mathrm{ONep})_{14} \mathrm{OSi}(\mathrm{Me})_{2}\right.$

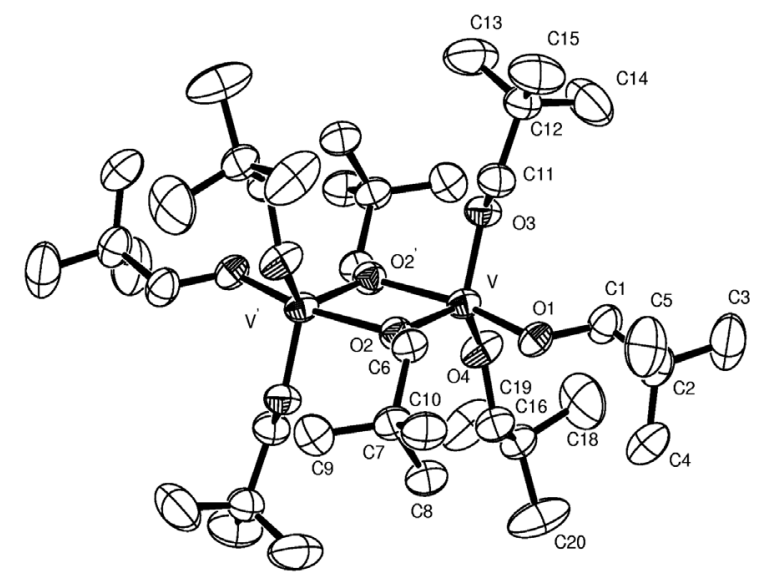

Figure 1. Representation of the molecular structure of $\left[\mathrm{V}_{2}(\mu-\mathrm{ONep})_{2}(\mathrm{ONep})_{6}\right], \mathrm{Nep}=$ neopentyl, employed as starting material for the synthesis of complexes $\mathbf{1}$ and $\mathbf{2} .{ }^{15}$ Thermal ellipsoids are drawn at the $50 \%$ probability level.
$\left.(\mathrm{ONep})\}_{2}\right] \cdot \mathrm{C}_{6} \mathrm{H}_{14}$, product $\mathbf{1}$, in the presence of the grease, or the desired $\left[\mathrm{V}(\mathrm{ONep})_{3}(\mu-\mathrm{ONep})_{2} \mathrm{Li}(\text { thf })_{2}\right] \cdot \mathrm{NepOH}$, thf $=$ tetrahydrofuran, product 2 , when the reaction was carried out without grease. Both preparations are readily reproducible. Reactions of lithium-containing compounds or Grignard reagents with silicone grease are not a novelty in the literature ${ }^{16,17}$ however, to our knowledge, this has not been reported before for vanadium systems. The products are promising precursors for mixed metal oxides with vanadium in the $+\mathrm{III} /+\mathrm{IV}$ oxidation states and, in the case of $\mathbf{1}$, also for $\mathrm{V} / \mathrm{Si} / \mathrm{Li}$-containing composites.

\section{Experimental}

All reactions were performed under an inert dinitrogen atmosphere with the use of standard Schlenk and glovebox (Nexus System 2000, Vacuum Atmospheres Co.) techniques. Solvents were dried and distilled under $\mathrm{N}_{2}$ prior to use. ${ }^{18}$ Commercial 2,2-dimethyl-1-propanol (neopentanol, neopentyl alcohol, Aldrich) was used as purchased. Dow Corning ${ }^{\circledR}$ high vacuum silicone grease was employed as a lubricant for ground glass joints unless otherwise stated. Lithium neopentoxide, $\left[\left\{\mathrm{Li}\left(\mu_{3}-\mathrm{ONep}\right)\right\}_{8}\right]$, and $\left[\mathrm{VCl}_{3}(\mathrm{thf})_{3}\right]$ were prepared in quantitative yield by published methods. ${ }^{14}$

Elemental $(\mathrm{C}, \mathrm{H}, \mathrm{N})$ analyses were carried out by Medac Laboratories Ltd. (Surrey, UK). Silicon contents were determined by atomic absorption spectrometry at the Institute of Chemistry, University of Campinas, Brazil, using Analytik Jena Nova 300 equipment. Samples were dissolved in aqueous $\mathrm{HNO}_{3}$ or $\mathrm{HCl}\left(3 \mathrm{~mol} \mathrm{~L}^{-1}\right)$ before analysis, and AccuTrace standard solutions $\left(1000 \mu \mathrm{g} \mathrm{mL}^{-1}\right)$ were employed for instrument calibration.

FTIR spectra were recorded on a BIORAD FTS$3500 \mathrm{GX}$ instrument in the $400-4000 \mathrm{~cm}^{-1}$ range, from Nujol mulls spread on KBr plates. Magnetic susceptibility measurements were carried out by a modified Gouy method in the solid state at room temperature, using a MKII magnetic susceptibility balance from Johnson-Matthey. Corrections for the diamagnetism of the ligands were applied by the use of Pascal constants. ${ }^{19}$

CW-EPR experiments were performed at X-band using a Bruker ESP-300E spectrometer equipped with a rectangular $\mathrm{TE}_{102}$ resonator (Bruker $4102 \mathrm{ST}$ ) at both liquid nitrogen $(77 \mathrm{~K})$ and room temperatures. Crystalline samples were dissolved in tetrahydrofuran for solution studies or powdered in a ceramic mortar for analysis in the solid state. Common experimental parameters were field modulation amplitude of $0.01 \mathrm{mT}$, conversion time of $40.96 \mathrm{~ms}$ per point, and time constant of $81.92 \mathrm{~ms}$. All EPR spectra simulations were carried out with the EasySpin software 
package for the Matlab ${ }^{\circledR}$ platform. ${ }^{20}$ The best parameter set search was optimized using the simplex algorithm.

NMR experiments were carried out at $295 \mathrm{~K}$ in nondeuterated thf containing some toluene- $d_{8}$ (lock signal), on a Bruker AVANCE 400 spectrometer operating at $9.4 \mathrm{~T}$ and equipped with a $5 \mathrm{~mm}$ multinuclear direct detection probe. Because of the low solubility of complex $\mathbf{1}$, the sample was prepared by heating a saturated solution (with some excess of solid) under ultrasonic treatment; this procedure gave a clear, light brown-pinkish solution that did not precipitate on cooling to room temperature. ${ }^{29} \mathrm{Si}\left\{{ }^{1} \mathrm{H}\right\}$ spectra $(79.49 \mathrm{MHz})$ were acquired with the inverse gated-decoupling pulse sequence ( ${ }^{1} \mathrm{H}$ decoupling only during acquisition) and 30 degree excitation pulses. Acquisition parameters were 500 ppm spectral width and $10 \mathrm{~s}$ relaxation delay. Processing employed zero-filling to $128 \mathrm{~K}$ data points and an exponential multiplication of the FID by a factor of $2 \mathrm{~Hz} .{ }^{29} \mathrm{Si}$ NMR chemical shifts are given in ppm related to the tetramethylsilane signal (tms, $0.0 \mathrm{ppm}$ ) as internal reference.

\section{Synthesis of $\left[\mathrm{V}_{2}(\mu \text {-ONep })_{2}(\mathrm{ONep})_{6}\right]$}

This preparation was based on a report by Haaland et al. ${ }^{21}$ $\left[\mathrm{VCl}_{3}(\mathrm{thf})_{3}\right](4.78 \mathrm{~g}, 12.8 \mathrm{mmol})$ was added slowly over $24 \mathrm{~h}$ to a boiling white suspension of $\left[\left\{\mathrm{Li}\left(\mu_{3}-\mathrm{ONep}\right)\right\}_{8}\right](5.05 \mathrm{~g}$, $6.72 \mathrm{mmol})$ in hexane/thf $(2.5: 1)$. This produced a dark blue suspension, which received the addition of copper(I) chloride (1.37 g, $12.8 \mathrm{mmol})$. The redox reaction was immediate, forming a dark green suspension containing a red solid, which was stirred at room temperature for $24 \mathrm{~h}$ and then filtered. The green filtrate was concentrated in vacuum and kept at $-20{ }^{\circ} \mathrm{C}$ for 5 days to give yellowish-green crystals of $\left[\mathrm{V}_{2}(\mu-\mathrm{ONep})_{2}(\mathrm{ONep})_{6}\right](2.03 \mathrm{~g}, 40 \%$ yield $)$. These were isolated by filtration and dried under vacuum. Anal. Calc. for $\mathrm{C}_{40} \mathrm{H}_{88} \mathrm{O}_{8} \mathrm{~V}_{2}: \mathrm{C}, 60.11 ; \mathrm{H}, 11.11$. Found: C, 59.05; H, $11.05 \%$.

Synthesis of $\left[\mathrm{V}_{6} \mathrm{Li}_{10} \mathrm{O}_{8}(\mathrm{ONep})_{14}\left\{\mathrm{OSi}(\mathrm{Me})_{2}(\mathrm{ONep})\right\}_{2}\right]$ $\cdot \mathrm{C}_{6} \mathrm{H}_{14}(\mathbf{1})$

A blue-greenish solution of $\left[\mathrm{V}_{2}(\mu-\mathrm{ONep})_{2}(\mathrm{ONep})_{6}\right]$ $(0.89 \mathrm{~g}, 1.11 \mathrm{mmol})$ in $30 \mathrm{~mL}$ of thf was added to a colourless solution of $\left[\left\{\mathrm{Li}\left(\mu_{3}-\mathrm{ONep}\right)\right\}_{8}\right](0.21 \mathrm{~g}, 0.27 \mathrm{mmol})$ in $10 \mathrm{~mL}$ of thf to give a light green solution, which changed to olive green after stirring at room temperature for $24 \mathrm{~h}$. The solvent was then taken to dryness under vacuum and the dark green slurry was dissolved in $10 \mathrm{~mL}$ of hexane and kept at room temperature for 5 days. Olive-brown crystals of 1 (0.35 g, $76 \%$ yield) were isolated by filtration and dried under vacuum. Product $\mathbf{1}$ is insoluble in toluene, hexane and poorly soluble both in thf and in a 2:1 neopentanol/thf mixture. Anal. Calc. for $\mathrm{C}_{84} \mathrm{H}_{188} \mathrm{Li}_{10} \mathrm{O}_{26} \mathrm{Si}_{2} \mathrm{~V}_{6} \cdot \mathrm{C}_{6} \mathrm{H}_{14}$ (1): C, 50.67; H, 9.55; Si, 2.63. Found: C, 49.86; H, 9.62; Si, $3.00 \%$.

\section{Synthesis of $\left[\mathrm{V}(\mathrm{ONep})_{3}(\mu-\mathrm{ONep})_{2} \mathrm{Li}(\mathrm{thf})_{2}\right] \cdot \mathrm{NepOH}(2)$}

In this preparation, the contact of solvents or reaction mixtures with silicone grease was carefully avoided. Poly(tetrafluoroethene) (PTFE) sleeves were employed in the place of the grease to protect all ground glass joints.

A blue-greenish solution of $\left[\mathrm{V}_{2}(\mu-\mathrm{ONep})_{2}(\mathrm{ONep})_{6}\right]$ $(1.70 \mathrm{~g}, 2.13 \mathrm{mmol})$ in $30 \mathrm{~mL}$ of thf was added to a colourless solution of $\left[\left\{\mathrm{Li}\left(\mu_{3}-\mathrm{ONep}\right)\right\}_{8}\right](0.42 \mathrm{~g}, 0.55 \mathrm{mmol})$ in $10 \mathrm{~mL}$ of thf, giving a dark green solution after stirring at room temperature for $24 \mathrm{~h}$. The reaction mixture was then taken to dryness under vacuum, leaving a light green solid that was redissolved in $10 \mathrm{~mL}$ of hexane containing $0.44 \mathrm{~g}$ (4.99 mmol) of NepOH. After stirring for $24 \mathrm{~h}$ at room temperature, the resulting greenish-yellow solution was cooled down to $-20^{\circ} \mathrm{C}$ for 2 days. Pale green crystals of 2 were then formed, which were isolated by filtration and dried under vacuum. Yield: $1.95 \mathrm{~g}, 63 \%$. Anal. Calc. for $\mathrm{C}_{33} \mathrm{H}_{71} \mathrm{LiO}_{7} \mathrm{~V} \cdot \mathrm{C}_{5} \mathrm{H}_{12} \mathrm{O}(2)$ : C, 62.85; H, 11.53. Found: $\mathrm{C}, 62.51 ; \mathrm{H}, 11.86 \%$. Product $\mathbf{2}$ is soluble in thf, toluene and in mixtures of hexane/thf (1:2), toluene/NepOH (3:1) and thf/NepOH (2:1). It is also partially soluble in hexane and in a $1: 1$ hexane/thf mixture.

\section{Crystal structure analyses of products 1 and 2}

For each sample, one crystal was mounted under oil on a glass fibre and fixed in the cold nitrogen stream on an Oxford Diffraction Xcalibur-3 CCD diffractometer equipped with Mo- $\mathrm{K}_{\alpha}$ radiation $(\lambda=0.71069 \AA)$ and graphite monochromator. Intensity data were measured by thin-slice $\omega$ - and $\varphi$-scans. Data were processed using the CrysAlis-CCD and -RED programs. ${ }^{22}$ The structures were determined by the direct methods routines in the SHELXS program $^{23}$ and refined by full-matrix least-squares methods, on $\mathrm{F}^{2}$ 's, in SHELXL. ${ }^{23}$

In complex 1 (olive-brown plates), the non-hydrogen atoms (except for the lithium atoms) were refined with anisotropic thermal parameters. Hydrogen atoms were included in idealised positions and their $\mathrm{U}_{\text {iso }}$ values were set to ride on the $\mathrm{U}_{\text {eq }}$ values of the parent carbon atoms. At the conclusion of the refinement, ${ }^{23} \mathrm{wR}_{2}=0.152$ and $\mathrm{R}_{1}=0.112$ for all 8001 reflections weighted $w=\left[\sigma^{2}\left(\mathrm{~F}_{\mathrm{o}}{ }^{2}\right)+(0.0718 \mathrm{P})^{2}\right]^{-1}$ with $\mathrm{P}=\left(\mathrm{F}_{\mathrm{o}}^{2}+2 \mathrm{~F}_{\mathrm{c}}^{2}\right) / 3$; for the 'observed' data only, $\mathrm{R}_{1}=0.063$. In the final difference map, the highest peak (ca. $0.6 \mathrm{e}^{-} \AA^{-3}$ ) was close to $\mathrm{O}(14)$. The unit cell contains one solvent (hexane) molecule per $\left\{\mathrm{V}_{6} \mathrm{Li}_{10}\right\}$ aggregate. 
Crystals of $\mathbf{2}$ (pale green prisms) contain two independent $\mathrm{V}$-Li complex molecules and two solvent (neopentanol) molecules in the asymmetric unit. One of the complex molecules shows disorder in three of its ligands; these have all been resolved, but in the refinement, the parameters of some atoms, common to more than one ligand orientation, have been tied together. The non-hydrogen atoms, except for a few of low-occupancy components, were refined with anisotropic thermal parameters. Hydrogen atoms were included in idealised positions and their $\mathrm{U}_{\text {iso }}$ values were set to ride on the $\mathrm{U}_{\mathrm{eq}}$ values of the parent carbon atoms. At the conclusion of the refinement, ${ }^{23} \mathrm{wR}_{2}=0.175$ and $\mathrm{R}_{1}=0.129$ for all 10128 reflections weighted $\mathrm{w}=\left[\sigma^{2}\left(\mathrm{~F}_{\mathrm{o}}{ }^{2}\right)+\right.$ $\left.(0.0918 \mathrm{P})^{2}\right]^{-1}$ with $\mathrm{P}=\left(\mathrm{F}_{\mathrm{o}}^{2}+2 \mathrm{~F}_{\mathrm{c}}{ }^{2}\right) / 3$; for the 'observed' data only, $R_{1}=0.066$. In the final difference map, the highest peak (ca. $\left.0.35 \mathrm{e}^{-} \AA^{-3}\right)$ was close to $\mathrm{V}(1)$.
Scattering factors for neutral atoms were taken from reference 24. Computer programs used in these analyses were run through WinGX ${ }^{25}$ on a Dell Precision 370 PC; diagrams were drawn with ORTEP3 for Windows. ${ }^{25}$ Crystal data and refinement results were compiled in Table 1.

\section{Results and Discussion}

The $1: 2$ reaction of $\left[\mathrm{V}_{2}(\mu-\mathrm{ONep})_{2}(\mathrm{ONep})_{6}\right]$ (Figure 1) with "Li(ONep)" in tetrahydrofuran was carried out according to a synthetic route reported by Hampden-Smith et al. ${ }^{6}$ for the preparation of complexes with the general formula "MTi $\left(\mathrm{OPr}^{\mathrm{i}}\right)_{5}$ ", $\mathrm{OPr}^{\mathrm{i}}=$ isopropoxide; $\mathrm{M}=\mathrm{Li}, \mathrm{Na}$, $\mathrm{K}$. The procedures employed in the present work gave olive-brown crystals of $\mathbf{1}$ and pale green crystals of $\mathbf{2}$ at room temperature; the difference is related to the use of

Table 1. Crystal and structure refinement data for $\left[\mathrm{V}_{6} \mathrm{Li}_{10} \mathrm{O}_{8}(\mathrm{ONep})_{14}\left[\mathrm{OSi}(\mathrm{Me})_{2}(\mathrm{ONep})\right\}_{2}\right] \cdot \mathrm{C}_{6} \mathrm{H}_{14}(\mathbf{1})$ and $\left[\mathrm{V}(\mathrm{ONep})_{3}(\mu-\mathrm{ONep})_{2} \mathrm{Li}(\text { thf })_{2}\right] \cdot \mathrm{NepOH}(\mathbf{2})$

\begin{tabular}{|c|c|c|}
\hline & 1 & 2 \\
\hline Empirical formula & $\mathrm{C}_{84} \mathrm{H}_{188} \mathrm{Li}_{10} \mathrm{O}_{26} \mathrm{Si}_{2} \mathrm{~V}_{6} \cdot \mathrm{C}_{6} \mathrm{H}_{14}$ & $\mathrm{C}_{33} \mathrm{H}_{71} \mathrm{LiO}_{7} \mathrm{~V} \cdot \mathrm{C}_{5} \mathrm{H}_{12} \mathrm{O}$ \\
\hline Formula weight $/\left(\mathrm{g} \mathrm{mol}^{-1}\right)$ & 2131.7 & 725.9 \\
\hline Crystal size / mm & $0.41 \times 0.27 \times 0.10$ & $0.48 \times 0.30 \times 0.18$ \\
\hline Colour & olive-brown plate & pale green prism \\
\hline Temperature / K & $140(1)$ & $140(1)$ \\
\hline Crystal system & triclinic & triclinic \\
\hline Space group & $P-1$ & $I-1$ (equiv. to number 2) \\
\hline $\mathrm{a} / \AA$ & $13.9928(8)$ & $17.7975(7)$ \\
\hline $\mathrm{b} / \AA$ & 14.7954(9) & $18.5833(7)$ \\
\hline c/ $/ \AA$ & $17.1392(12)$ & $27.9979(11)$ \\
\hline$\alpha /{ }^{\circ}$ & $93.568(5)$ & $89.439(3)$ \\
\hline$\beta / \circ$ & $102.792(6)$ & $90.617(3)$ \\
\hline$\gamma / \circ$ & $115.535(6)$ & $96.973(3)$ \\
\hline $\mathrm{V} / \AA^{3}$ & $3071.7(3)$ & $9190.6(6)$ \\
\hline $\mathrm{F}(000)$ & 1146 & 3208 \\
\hline $\mathrm{Z}$ & 1 & 8 \\
\hline$\rho_{\text {calcd }} /\left(\mathrm{mg} \mathrm{m}^{-3}\right)$ & 1.152 & 1.049 \\
\hline Absorption coefficient / $\mathrm{mm}^{-1}$ & 0.516 & 0.257 \\
\hline$\theta$ range for data collection $/^{\circ}$ & 3.2 to 22.5 & 3.3 to 21.25 \\
\hline Reflections collected & 26062 & 33386 \\
\hline Independent reflections & $8001[\mathrm{R}$ (int) for equivalents $=0.092]$ & $10128[\mathrm{R}(\mathrm{int})$ for equivalents $=0.087]$ \\
\hline Reflections with $I>2 \sigma_{I}$ & 5123 & 5757 \\
\hline Parameters refined & 581 & 967 \\
\hline Completeness to $\theta_{\max } / \%$ & 99.6 & 99.4 \\
\hline Largest diff. peak and hole / $\left(\mathrm{e}^{-} \AA^{-3}\right)$ & 0.62 and -0.49 & 0.35 and -0.24 \\
\hline$R_{1}, w R_{2}\left(I>2 \sigma_{I}\right)^{23}$ & $0.063,0.139^{\text {(a) }}$ & $0.066,0.151^{(b)}$ \\
\hline$R_{1}, w R_{2}$ (all data) ${ }^{23}$ & $0.112,0.152^{\text {(a) }}$ & $0.129,0.175^{(\mathrm{b})}$ \\
\hline
\end{tabular}

(a),(b) Reflections weighted: ${ }^{(a)} \mathrm{W}=\left[\sigma^{2}\left(\mathrm{~F}_{\mathrm{o}}{ }^{2}\right)+(0.0718 \mathrm{P})^{2}\right]^{-1}$, where $\mathrm{P}=\left(\mathrm{F}_{\mathrm{o}}{ }^{2}+2 \mathrm{~F}_{\mathrm{c}}{ }^{2}\right) / 3 ;{ }^{(\mathrm{b})} \mathrm{W}=\left[\sigma^{2}\left(\mathrm{~F}_{\mathrm{o}}{ }^{2}\right)+(0.0918 \mathrm{P})^{2}\right]^{-1}$, where $\mathrm{P}=\left(\mathrm{F}_{\mathrm{o}}{ }^{2}+2 \mathrm{~F}_{\mathrm{c}}{ }^{2}\right) / 3$. 


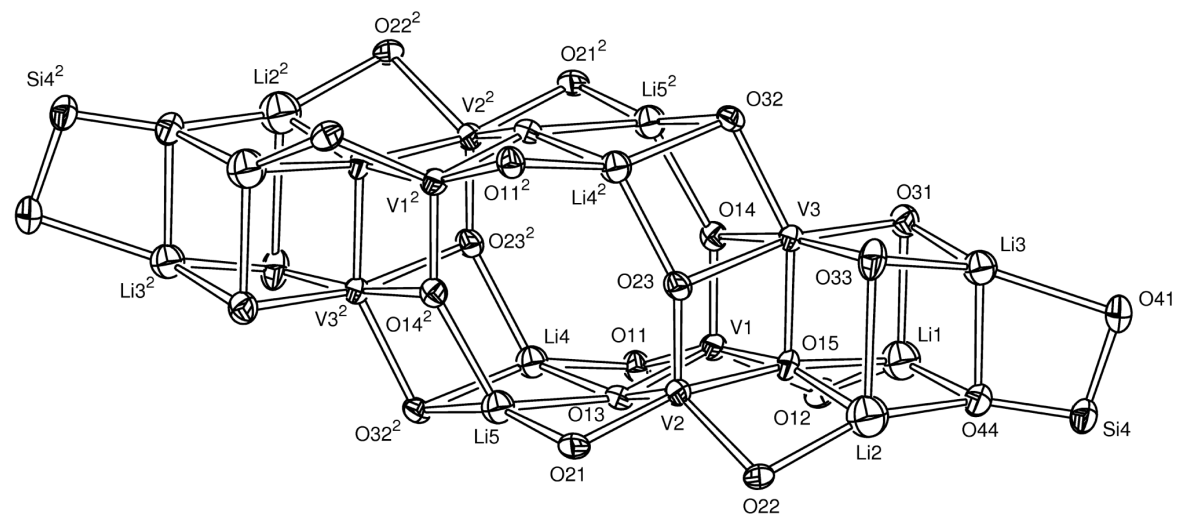

Figure 2. View of the complete skeleton of the centrosymmetric $\left[\mathrm{V}_{6} \mathrm{Li}_{10} \mathrm{O}_{8}(\mathrm{ONep})_{14}\left\{\mathrm{OSi}(\mathrm{Me})_{2}(\mathrm{ONep})\right\}_{2}\right]$ molecule (1).

silicone grease in the Schlenk-type glassware during the preparation of $\mathbf{1}$.

Analytical and spectroscopic data for $\mathbf{1}$ are consistent with the formulation $\left[\mathrm{V}_{6} \mathrm{Li}_{10} \mathrm{O}_{8}(\mathrm{ONep})_{14}\left\{\mathrm{OSi}(\mathrm{Me})_{2}(\mathrm{ONep})\right\}_{2}\right]$ $\cdot \mathrm{C}_{6} \mathrm{H}_{14}$, revealed by single crystal $\mathrm{X}$-ray diffraction analysis. The high reactivity of the $\mathrm{V}^{\mathrm{IV}} / \mathrm{Li}^{\mathrm{I}}$ alkoxide system, together with its contact with the silicone grease used for sealing the ground glass joints, determined a reaction pathway different from the expected, as revealed by the crystallographic structure of $\mathbf{1}$ (Figures 2 and 3). The molecular aggregate contains sixteen metal centres and two silanolate units, $\left\{\mathrm{OSi}\left(\mathrm{Me}_{2}\right)(\mathrm{ONep})\right\}^{-}$, the latter provided by the grease. The incorporation of these groups probably followed a nucleophilic attack of neopentoxides on the silicon centres of the $\left(\mathrm{OSiMe}_{2}\right)_{\mathrm{n}}$ polymer. To the best of our knowledge, this is the first report of this type of reaction involving a vanadium (oxo)alkoxide, and one of a few related reports with d-block metal complexes. ${ }^{17}$ In spite of the accidental nature of this synthesis in the context of the present work, the preparation of $\mathbf{1}$ is perfectly reproducible in the conditions described in Experimental.

Silicone grease is a linear polymer that consists of chains of alternating dimethylsilylene units and oxygen atoms, $\left(-\mathrm{SiMe}_{2}-\mathrm{O}-\right)_{\mathrm{n}}$, terminated in most cases with $\mathrm{Si}-\mathrm{OH}$ groups. Its partial solubility in tetrahydrofuran facilitates extraction into reaction mixtures containing this solvent. Accidental contact with reactive, highly polar metal-containing species may lead, as in the present case, to unexpected species in solution. Some interesting new compounds have been reported as a result of such combinations, and the subject has drawn the attention of many researchers. These compounds frequently contain large molecular aggregates (sometimes supramolecular assemblies) including polysiloxane grease fragments such as dimethylsilylene and oligosiloxane units. ${ }^{16}$

Product 2 , in its turn, was prepared and manipulated in the absence of silicone grease. In this case,

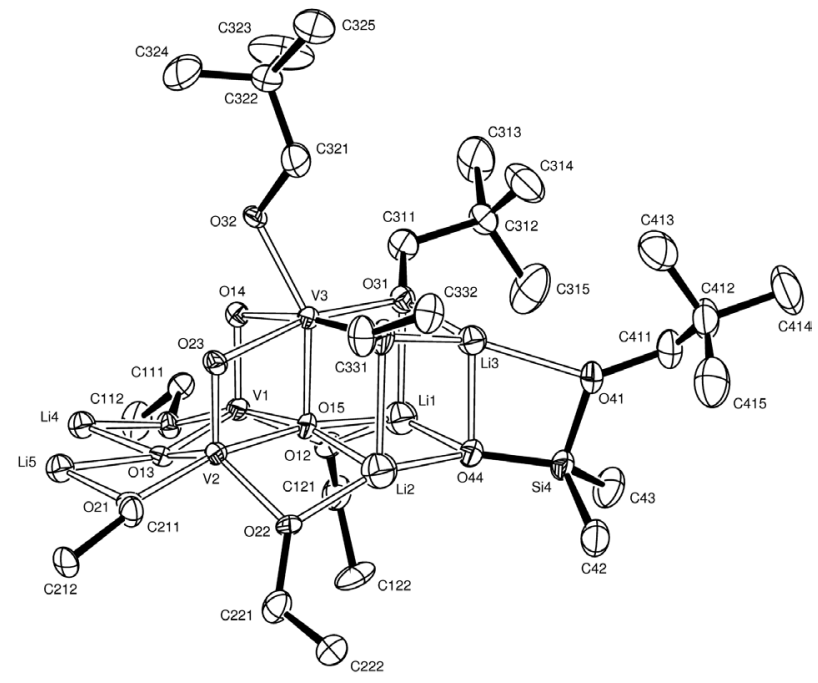

Figure 3. View of one half of the molecular aggregate (1), indicating the atom numbering scheme. Some of the methyl groups and the hydrogen atoms have been omitted for clarity. Thermal ellipsoids are drawn at the $50 \%$ probability level.

poly(tetrafluoroethene) (PTFE) sleeves were employed in all synthetic and analytical steps, starting from solvent purification. Differently from those reported for analogous $\mathrm{Li}^{\mathrm{I}}-\mathrm{Ti}^{\mathrm{IV}}$ alkoxides $\left(\mathrm{R}=\mathrm{Pr}^{\mathrm{i}} \text { or } \mathrm{Nep}\right)^{6}$ and $\mathrm{Li}^{\mathrm{I}}-\mathrm{Nb}^{\mathrm{V}}$ neopentoxides, ${ }^{26}$ the metal centres in complex 2 do not aggregate to give a tetranuclear $\left\{\mathrm{M}_{2} \mathrm{Li}_{2}\right\}$ or a higher nuclearity core ( $\mathrm{M}=$ transition metal). Instead, binuclear 2 resembles one-half of the vanadium(IV) starting molecule (Figure 1), this time connected to a $\left\{\mathrm{Li}(\text { thf })_{2}\right\}$ moiety (Figure 4). In fact, the product is simply a V(OR) . $^{\text {(solvated }}$ LiOR) adduct, in which the formation of the neopentoxide bridges and the Lewis basicity of thf determine the completion of the metal coordination spheres. The absence of further aggregation is probably related both to the choice of an electron-donating solvent and the fact that non-oxo vanadium(IV) does not commonly reach six-coordination with monodentate, branched alkoxides. To the best of our knowledge, octahedral (homoleptic) alkoxides of non- 
oxo $\mathrm{V}^{\mathrm{IV}}$ are only found with ligands such as methoxide, ethoxide or chelating OR groups, such as those generated from monosaccharides. ${ }^{27}$

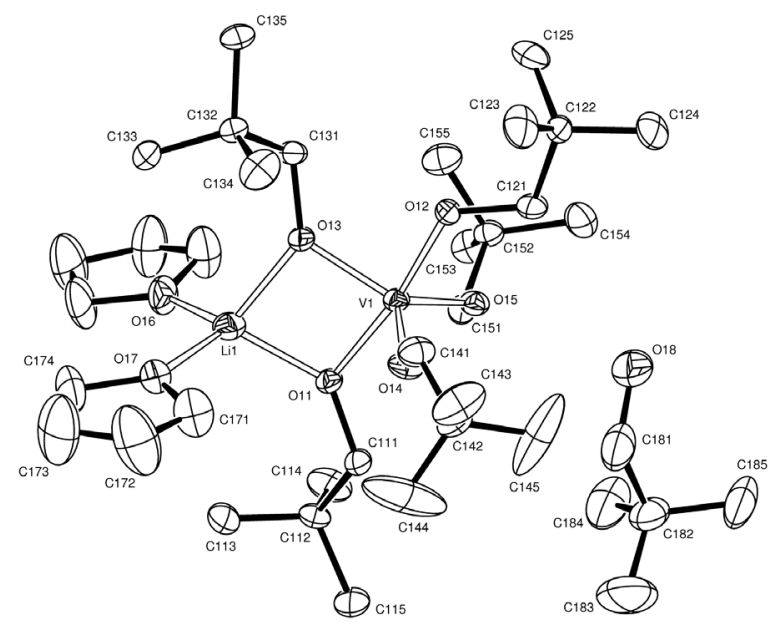

Figure 4. One of the V-Li complex molecules (2) with its $\mathrm{NepOH}$ neighbour. Thermal ellipsoids are drawn at the $50 \%$ probability level.

Product $\mathbf{2}$ is highly soluble in thf and constitutes a suitable starting material for the preparation of mixed transition metal complexes by salt (LiX) elimination reactions. It has already been employed in our laboratory to produce $\mathrm{Li} / \mathrm{V}$ oxide films for electrochemical applications, with promising preliminary results.

\section{Solid state structures}

\section{Complex 1}

The solid state structure of compound $\mathbf{1}$, determined by single crystal X-ray diffraction analysis, consists of $\left[\mathrm{V}_{6} \mathrm{Li}_{10}\right.$ $\left.\mathrm{O}_{8}(\mathrm{ONep})_{14}\left\{\mathrm{OSi}(\mathrm{Me})_{2}(\mathrm{ONep})\right\}_{2}\right] \cdot \mathrm{C}_{6} \mathrm{H}_{14}$ molecules, one in each triclinic ( $(P-1)$ unit cell (Figures 2 and 3). It illustrates the type of species that may be present in solution after accidental contact of lithium-containing reagents with silicone grease; accordingly, some of the structural features of $\mathbf{1}$ have been seen in other studies. ${ }^{14,16}$ On the other hand, this particular structure presents a distinctive condensed system composed of a 24-atom cyclic unit and two distorted heterocubanes, $\left\{\mathrm{VLi}_{3} \mathrm{O}_{4}\right\}$, one on each side of the central, wheel-like aggregate.

The complex lies about an inversion centre, which relates two distinct types of vanadium, $\mathrm{V}(1) / \mathrm{V}(2)$ and $\mathrm{V}(3)$, and three non-equivalent types of lithium centres, $\mathrm{Li}(1) / \mathrm{Li}(2), \operatorname{Li}(3)$ and $\operatorname{Li}(4) / \mathrm{Li}(5)$, with their symmetry counterparts. The central cyclic unit is formed by $\mathrm{O}(15)$, $\mathrm{V}(1), \mathrm{V}(2), \mathrm{V}(3), \mathrm{O}(14), \mathrm{O}(23), \mathrm{O}(32), \mathrm{O}(11), \mathrm{O}(13), \mathrm{O}(21)$, $\mathrm{Li}(4), \mathrm{Li}(5)$ and their symmetry-related atoms (Figures 2 and 3). Because of this inversion symmetry, the complex could also be formulated as $\left[\left(\mathrm{V}_{3} \mathrm{Li}_{5} \mathrm{O}_{4}(\mathrm{ONep})_{7}\left\{\mathrm{OSi}(\mathrm{Me})_{2}\right.\right.\right.$
(ONep) $\})_{2}$ ]. The following discussion will be focused on the independent half-molecule.

The $\mathrm{V}(3)$ and $\mathrm{O}(15)$ centres are common to the ring and the cubane units; the latter also involves $\operatorname{Li}(1), \operatorname{Li}(2)$, $\mathrm{O}(44), \mathrm{Li}(3), \mathrm{O}(31)$ and $\mathrm{O}(33)$. The structure also contains $\left\{\mathrm{OSi}(\mathrm{Me})_{2}(\mathrm{ONep})\right\}^{-}$groups acting both as chelating ligands to $\mathrm{Li}(3)$ and bridging ligands for $\mathrm{Li}(1)$ and $\mathrm{Li}(2)$. Welldefined neopentyl groups are bound to oxygen centres $11,21,12,22,31,32,33$ and 41 , while three-coordinate $\mathrm{O}(14) / \mathrm{O}(23)$, four-coordinate $\mathrm{O}(13)$ and five-coordinate $\mathrm{O}(15)$ are oxo groups (Figure 3 ).

The triangle formed by the $\mathrm{V}(1), \mathrm{V}(2)$ and $\mathrm{V}(3)$ centres is connected to the five-coordinate $\mathrm{O}(15)$, which is also linked to $\mathrm{Li}(1)$ and $\mathrm{Li}(2)$. This oxo group, $\mathrm{O}(15)$, is a key component of the whole assembly, as it holds five out of the eight metal centres in each half of the aggregate. The square-pyramidal arrangement about $\mathrm{O}(15)$ resembles that observed in $\left[\mathrm{Fe}_{5}\left(\mu_{5}-\mathrm{O}\right)\left(\mu-\mathrm{OPr}^{\mathrm{i}}\right)_{8} \mathrm{Cl}_{5}\right]^{28}$ and a number of related iron ${ }^{29}$ and lanthanide complexes, ${ }^{30}$ this time generating a novel pentanuclear $\left\{\mathrm{V}_{3} \mathrm{Li}_{2}\right\}$ motif which is, in itself, another relevant structural component of $\mathbf{1}$. The other oxo ligands, namely the four-coordinate $\mathrm{O}(13)$ and the three-coordinate $\mathrm{O}(14)$ and $\mathrm{O}(23)$, help in stabilizing and shaping the cyclic framework.

The highly distorted octahedral geometry about the $\mathrm{V}(3)$ centre is determined by the neopentoxide and oxo bridges involved in the formation of the cubane and ring units. This distortion can be clearly seen in Figures 2 and 3 and is exemplified by the angles $\mathrm{O}(14)-\mathrm{V}(3)-\mathrm{O}(33)$ $\left[168.36(13)^{\circ}\right], \mathrm{O}(23)-\mathrm{V}(3)-\mathrm{O}(31)\left[167.74(13)^{\circ}\right]$ and $\mathrm{O}(15)-\mathrm{V}(3)-\mathrm{O}(32)\left[150.94(14)^{\circ}\right]$, well away from the ideal octahedral figures (Table 2). Vanadium(IV) centres V(1) and $\mathrm{V}(2)$ are distorted trigonal bipyramidal, as revealed by the $\mathrm{O}(15)-\mathrm{V}(1)-\mathrm{O}(11)\left[163.40(14)^{\circ}\right], \mathrm{O}(13)-\mathrm{V}(1)-$ $\mathrm{O}(14)\left[107.81(15)^{\circ}\right], \mathrm{O}(15)-\mathrm{V}(2)-\mathrm{O}(21)\left[165.44(14)^{\circ}\right]$ and $\mathrm{O}(13)-\mathrm{V}(2)-\mathrm{O}(15)\left[84.51(15)^{\circ}\right]$ angles (Tables 2 and S1). The vanadium-oxygen bond lengths fall in the range observed for other vanadium polyoxoalkoxides, as well as the mean $\mathrm{V}-\mu_{5}-\mathrm{O}[1.992(4) \AA]>\mathrm{V}-\mu_{4}-\mathrm{O}[1.892(4) \AA]$ > $\mathrm{V}-\mu_{3}-\mathrm{O}[1.673(3) \AA]$ distances. ${ }^{31} \mathrm{The} \mathrm{V}(1)-\mathrm{O}(14)$ and $\mathrm{V}(2)$ $\mathrm{O}(23)$ bond lengths (1.667(3) and 1.678(3) Å respectively) are significantly shorter than the other $\mathrm{V}-\mathrm{O}$ bond distances about the five-coordinate vanadium centres (mean value 1.929(4) §), evidencing, in the former, a marked double bond $(\mathrm{V}=\mathrm{O})$ character.

The average value of the $\mathrm{Li}-\mathrm{O}_{(\mathrm{Nep})}$ distance in the cubane, 2.104(10) $\AA$, is larger than the related dimension in the $\left[\left\{\mathrm{Li}\left(\mu_{3}-\mathrm{ONep}\right)\right\}_{8}\right]$ starting material, $1.896(5) \AA$, in accordance with the different coordination numbers for lithium: four in the case of $\mathbf{1}$ and three in $\left[\left\{\mathrm{Li}\left(\mu_{3}-\mathrm{ONep}\right)\right\}_{8}\right]$. The same tendency is observed for the $\mathrm{Li}_{-} \mathrm{O}_{\text {(Nep) }}$ bonds 
Table 2. Selected molecular dimensions for $\left[\mathrm{V}_{6} \mathrm{Li}_{10} \mathrm{O}_{8}(\mathrm{ONep})_{14}\left\{\mathrm{OSi}(\mathrm{Me})_{2}(\mathrm{ONep})\right\}_{2}\right] \cdot \mathrm{C}_{6} \mathrm{H}_{14}(\mathbf{1})$. Bond lengths are in Ångstroms, angles in degrees. Standard deviations are in parentheses

\begin{tabular}{|c|c|c|c|}
\hline \multicolumn{4}{|c|}{ (a) About the vanadium atoms } \\
\hline $\mathrm{V}(1)-\mathrm{O}(11)$ & $1.919(4)$ & $\mathrm{V}(2)-\mathrm{O}(22)$ & $1.926(3)$ \\
\hline $\mathrm{V}(1)-\mathrm{O}(12)$ & $1.919(3)$ & $\mathrm{V}(2)-\mathrm{O}(23)$ & $1.678(3)$ \\
\hline $\mathrm{V}(1)-\mathrm{O}(13)$ & $1.902(4)$ & $\mathrm{O}(14)-\mathrm{V}(3)$ & $2.186(3)$ \\
\hline $\mathrm{V}(1)-\mathrm{O}(14)$ & $1.667(3)$ & $\mathrm{O}(15)-\mathrm{V}(3)$ & $1.949(3)$ \\
\hline $\mathrm{V}(1)-\mathrm{O}(15)$ & $1.980(4)$ & $\mathrm{O}(23)-\mathrm{V}(3)$ & $2.152(3)$ \\
\hline $\mathrm{O}(13)-\mathrm{V}(2)$ & $1.881(4)$ & $\mathrm{V}(3)-\mathrm{O}(31)$ & $1.980(4)$ \\
\hline $\mathrm{O}(15)-\mathrm{V}(2)$ & $2.004(4)$ & $\mathrm{V}(3)-\mathrm{O}(32)$ & $1.999(3)$ \\
\hline $\mathrm{V}(2)-\mathrm{O}(21)$ & $1.903(4)$ & $\mathrm{V}(3)-\mathrm{O}(33)$ & $1.936(4)$ \\
\hline $\mathrm{O}(11)-\mathrm{V}(1)-\mathrm{O}(12)$ & $95.61(15)$ & $\mathrm{O}(31)-\mathrm{V}(3)-\mathrm{O}(14)$ & $90.74(14)$ \\
\hline $\mathrm{O}(13)-\mathrm{V}(1)-\mathrm{O}(11)$ & $86.50(15)$ & $\mathrm{O}(32)-\mathrm{V}(3)-\mathrm{O}(14)$ & $81.09(13)$ \\
\hline $\mathrm{O}(14)-\mathrm{V}(1)-\mathrm{O}(11)$ & $106.04(16)$ & $\mathrm{O}(33)-\mathrm{V}(3)-\mathrm{O}(14)$ & $168.36(13)$ \\
\hline $\mathrm{O}(11)-\mathrm{V}(1)-\mathrm{O}(15)$ & $163.40(14)$ & $\mathrm{O}(15)-\mathrm{V}(3)-\mathrm{O}(23)$ & $78.50(13)$ \\
\hline $\mathrm{O}(13)-\mathrm{V}(1)-\mathrm{O}(12)$ & $135.04(15)$ & $\mathrm{O}(15)-\mathrm{V}(3)-\mathrm{O}(31)$ & $90.80(14)$ \\
\hline $\mathrm{O}(14)-\mathrm{V}(1)-\mathrm{O}(12)$ & $114.52(16)$ & $\mathrm{O}(15)-\mathrm{V}(3)-\mathrm{O}(32)$ & $150.94(14)$ \\
\hline $\mathrm{O}(12)-\mathrm{V}(1)-\mathrm{O}(15)$ & $80.95(15)$ & $\mathrm{O}(33)-\mathrm{V}(3)-\mathrm{O}(15)$ & $93.09(15)$ \\
\hline $\mathrm{O}(14)-\mathrm{V}(1)-\mathrm{O}(13)$ & $107.81(15)$ & $\mathrm{O}(31)-\mathrm{V}(3)-\mathrm{O}(23)$ & $167.74(13)$ \\
\hline $\mathrm{O}(13)-\mathrm{V}(1)-\mathrm{O}(15)$ & $84.66(15)$ & $\mathrm{O}(32)-\mathrm{V}(3)-\mathrm{O}(23)$ & $83.39(13)$ \\
\hline $\mathrm{O}(14)-\mathrm{V}(1)-\mathrm{O}(15)$ & $90.05(15)$ & $\mathrm{O}(33)-\mathrm{V}(3)-\mathrm{O}(23)$ & $91.79(15)$ \\
\hline $\mathrm{O}(21)-\mathrm{V}(2)-\mathrm{O}(15)$ & $165.44(14)$ & $\mathrm{O}(31)-\mathrm{V}(3)-\mathrm{O}(32)$ & $108.79(14)$ \\
\hline $\mathrm{O}(15)-\mathrm{V}(3)-\mathrm{O}(14)$ & $77.31(13)$ & $\mathrm{O}(33)-\mathrm{V}(3)-\mathrm{O}(31)$ & $82.73(15)$ \\
\hline $\mathrm{O}(23)-\mathrm{V}(3)-\mathrm{O}(14)$ & $92.71(13)$ & $\mathrm{O}(33)-\mathrm{V}(3)-\mathrm{O}(32)$ & $110.11(14)$ \\
\hline \multicolumn{4}{|c|}{ (b) About the lithium atoms } \\
\hline $\mathrm{Li}(1)-\mathrm{O}(12)$ & $1.898(11)$ & $\mathrm{Li}(3)-\mathrm{O}(41)$ & $2.175(10)$ \\
\hline $\mathrm{Li}(1)-\mathrm{O}(15)$ & $1.988(11)$ & $\mathrm{Li}(3)-\mathrm{O}(44)$ & $2.035(9)$ \\
\hline $\mathrm{Li}(1)-\mathrm{O}(31)$ & $2.140(10)$ & $\mathrm{Li}(5)-\mathrm{O}(13)$ & $2.074(10)$ \\
\hline $\mathrm{Li}(1)-\mathrm{O}(44)$ & $1.948(11)$ & $\operatorname{Li}(5)-\mathrm{O}\left(14^{\prime}\right)$ & $2.004(9)$ \\
\hline $\mathrm{Li}(3)-\mathrm{O}(31)$ & $1.942(10)$ & $\mathrm{Li}(5)-\mathrm{O}(21)$ & $1.911(10)$ \\
\hline $\mathrm{Li}(3)-\mathrm{O}(33)$ & $1.917(10)$ & $\mathrm{Li}(5)-\mathrm{O}\left(32^{\prime}\right)$ & $2.010(10)$ \\
\hline $\mathrm{O}(12)-\mathrm{Li}(1)-\mathrm{O}(15)$ & $81.2(4)$ & $\mathrm{O}(33)-\mathrm{Li}(3)-\mathrm{O}(41)$ & $141.6(5)$ \\
\hline $\mathrm{O}(12)-\mathrm{Li}(1)-\mathrm{O}(31)$ & $116.9(5)$ & $\mathrm{O}(33)-\mathrm{Li}(3)-\mathrm{O}(44)$ & $100.9(4)$ \\
\hline $\mathrm{O}(12)-\mathrm{Li}(1)-\mathrm{O}(44)$ & $147.4(6)$ & $\mathrm{O}(44)-\mathrm{Li}(3)-\mathrm{O}(41)$ & $73.8(3)$ \\
\hline $\mathrm{O}(15)-\mathrm{Li}(1)-\mathrm{O}(31)$ & $85.2(4)$ & $\mathrm{O}\left(14^{\prime}\right)-\mathrm{Li}(5)-\mathrm{O}(13)$ & $118.2(5)$ \\
\hline $\mathrm{O}(44)-\mathrm{Li}(1)-\mathrm{O}(15)$ & $95.1(5)$ & $\mathrm{O}(21)-\mathrm{Li}(5)-\mathrm{O}(13)$ & $82.6(4)$ \\
\hline $\mathrm{O}(44)-\mathrm{Li}(1)-\mathrm{O}(31)$ & $94.9(4)$ & $\mathrm{O}\left(32^{\prime}\right)-\mathrm{Li}(5)-\mathrm{O}(13)$ & $97.6(4)$ \\
\hline $\mathrm{O}(33)-\mathrm{Li}(3)-\mathrm{O}(31)$ & $84.3(4)$ & $\mathrm{O}(21)-\mathrm{Li}(5)-\mathrm{O}\left(14^{\prime}\right)$ & $111.3(4)$ \\
\hline $\mathrm{O}(31)-\mathrm{Li}(3)-\mathrm{O}(41)$ & $134.0(5)$ & $\mathrm{O}\left(14^{\prime}\right)-\mathrm{Li}(5)-\mathrm{O}\left(32^{\prime}\right)$ & $85.5(4)$ \\
\hline $\mathrm{O}(31)-\mathrm{Li}(3)-\mathrm{O}(44)$ & $98.5(4)$ & $\mathrm{O}(21)-\mathrm{Li}(5)-\mathrm{O}\left(32^{\prime}\right)$ & $160.9(5)$ \\
\hline \multicolumn{4}{|l|}{ (c) In the ligands } \\
\hline $\mathrm{Si}(4)-\mathrm{O}(41)$ & $1.675(4)$ & $\mathrm{Si}(4)-\mathrm{O}(44)$ & $1.595(4)$ \\
\hline $\mathrm{V}(2)-\mathrm{O}(13)-\mathrm{V}(1)$ & $97.45(16)$ & $\mathrm{V}(1)-\mathrm{O}(15)-\mathrm{Li}(1)$ & $91.8(3)$ \\
\hline $\mathrm{V}(1)-\mathrm{O}(13)-\mathrm{Li}(4)$ & $88.2(3)$ & $\mathrm{Li}(2)-\mathrm{O}(15)-\mathrm{V}(1)$ & $162.9(4)$ \\
\hline $\mathrm{V}(1)-\mathrm{O}(13)-\mathrm{Li}(5)$ & 159.4(3) & $\mathrm{V}(3)-\mathrm{O}(15)-\mathrm{V}(2)$ & $94.37(14)$ \\
\hline $\mathrm{V}(2)-\mathrm{O}(13)-\mathrm{Li}(4)$ & $158.0(3)$ & $\mathrm{Li}(1)-\mathrm{O}(15)-\mathrm{V}(2)$ & $170.2(3)$ \\
\hline V(2)-O(13)-Li(5) & $88.4(3)$ & $\mathrm{Li}(2)-\mathrm{O}(15)-\mathrm{V}(2)$ & $92.7(4)$ \\
\hline $\mathrm{Li}(4)-\mathrm{O}(13)-\mathrm{Li}(5)$ & $79.5(4)$ & $\mathrm{V}(3)-\mathrm{O}(15)-\mathrm{Li}(1)$ & $94.7(3)$ \\
\hline $\mathrm{V}(1)-\mathrm{O}(15)-\mathrm{V}(2)$ & $91.07(14)$ & $\mathrm{Li}(2)-\mathrm{O}(15)-\mathrm{V}(3)$ & $100.9(3)$ \\
\hline $\mathrm{V}(3)-\mathrm{O}(15)-\mathrm{V}(1)$ & $95.48(14)$ & $\mathrm{Li}(2)-\mathrm{O}(15)-\mathrm{Li}(1)$ & $81.9(5)$ \\
\hline
\end{tabular}

Symmetry transformations used to generate equivalent atoms: ' : 1-x, 1-y, 1-z 
involving $\operatorname{Li}(4)$ and $\operatorname{Li}(5)$ in the cyclic, central part of 1 (average $\mathrm{Li}_{-} \mathrm{O}_{\text {(Nep) }}$ bond length $=1.970(10) \AA$, Tables 2 and $\mathrm{S} 1)$, which are longer than the analogous bond length in $\left[\left\{\mathrm{Li}\left(\mu_{3}-\mathrm{ONep}\right)\right\}_{8}\right], 1.878(5) \AA .^{14}$

The central wheel-like, 24-atom aggregate appears distorted about the $\mu_{4}$-oxo groups, as the average $[\mathrm{V}(1) /$ $\mathrm{V}(2)]-\mathrm{O}(13)$ bond is $c a .0 .15 \AA$ shorter than the mean $[\mathrm{Li}(4) / \mathrm{Li}(5)]-\mathrm{O}(13)$ distance, even taking the standard deviation of the measurements into account [1.892(4) versus 2.054(10) $\AA$, respectively]. In the basal bonds about $\mu_{5}-\mathrm{O}(15)$, in their turn, the variation is much smaller: the average values for the vanadium- and lithium- $\mathrm{O}(15)$ bond lengths are 1.992(4) and 1.960(11) $\AA$, respectively, and show about one fifth of the previous difference. Additionally, the $\mathrm{V}(3)-\mathrm{O}(15)$ bond distance $[1.949(3) \AA]$ is shorter than the other $\mathrm{V}-\mathrm{O}$ bonds involving the $\mu_{5}$-oxygen; this stronger interaction with the apical metal centre is also found in similar $\left\{\mathrm{M}_{5}\left(\mu_{5}-\mathrm{O}\right)\right\}$ cores reported in the literature..$^{28-30}$

An additional, notable structural feature of $\mathbf{1}$ is the severely flattened "coordination" environment of $\mathrm{O}(13)$ in the central cyclic unit. The bond angles $\mathrm{V}(2)-\mathrm{O}(13)-\mathrm{V}(1), \mathrm{V}(2)$ $\mathrm{O}(13)-\mathrm{Li}(5), \mathrm{Li}(4)-\mathrm{O}(13)-\mathrm{Li}(5)$ and $\mathrm{V}(1)-\mathrm{O}(13)-\mathrm{Li}(4)$ add together to 353.5(3) $\AA$ (Table 2) and reveal a close-to-squareplanar $\mathrm{V}_{2} \mathrm{Li}_{2} \mathrm{O}$ core that bears a likeness to the $\left\{\mathrm{M}_{4} \mathrm{O}\right\}$ central units described for $\mu_{4}$-oxo-centered lanthanide clusters. Some of these clusters, for symmetry reasons, present an exactly planar arrangement. ${ }^{32}$ This is not the same for $\mathbf{1}$, where $\mathrm{O}(13)$ is $0.328(4) \AA$ out of the good mean-plane of $\mathrm{V}(1), \mathrm{V}(2), \mathrm{Li}(4)$ and $\operatorname{Li}(5)$, but still the bond dimensions are far away from the normal tetrahedral or distorted tetrahedral geometries generally described for $\mu_{4}$-oxo ligands. ${ }^{33}$

The putative vanadium(IV) centres, $\mathrm{V}(1) / \mathrm{V}(2)$, are each bound to two $\mu$-(ONep) groups, while vanadium(III), $\mathrm{V}(3)$, is connected to three $\mu_{3}-(\mathrm{ONep})$. The average value for the $\mathrm{V}-\mu-(\mathrm{ONep})$ distances involving vanadium(IV)
[V(1) and V(2); 1.917(4) $\AA$ ] is close to the observed for the analogous dimensions in the $\left[\mathrm{V}_{2}(\mu-\mathrm{ONep})_{2}(\mathrm{ONep})_{6}\right]$ starting material [mean bond length $=2.012(6) \AA],{ }^{15}$ as well as for its isopropoxide-containing analogue, $\left[\mathrm{V}_{2}\left(\mu-\mathrm{OPr}^{\mathrm{i}}\right)_{2}\left(\mathrm{OPr}^{\mathrm{i}}\right)_{6}\right]$, 2.012(10) $\AA .{ }^{11}$ For the vanadium(III) centre, the average $\mathrm{V}-\left(\mu_{3}-\mathrm{O}_{\mathrm{Nep}}\right)$ bond distance is $1.972(4) \AA$, and therefore the $\mathrm{V}-\mathrm{O}_{(\text {Nep })}$ bond lengths in $\mathbf{1}$ follow the trend $\mathrm{M}-(\mu-\mathrm{OR})<$ $\mathrm{M}-\left(\mu_{3}-\mathrm{OR}\right)$, which is compatible with the stepwise decrease in the available electron density about the bridging oxygen sites as the number of connected metal centres increases. ${ }^{28}$

The average values for the $\mathrm{Si}-\mathrm{C}$ and $\mathrm{Si}-\mathrm{O}$ distances in the $\left\{\mathrm{OSi}(\mathrm{Me})_{2}(\mathrm{ONep})\right\}$ - group [1.854(6) $\AA$ and 1.594(4) $\AA$, respectively] are close to those observed for $\left[\mathrm{Mg}_{2} \mathrm{Br}_{2}\left(\mathrm{C}_{8} \mathrm{H}_{11} \mathrm{OSi}\right)_{2}\left(\mathrm{C}_{4} \mathrm{H}_{10} \mathrm{O}\right)_{2}\right][1.861(2) \AA$ and $1.6342(12)$, respectively $]^{16}$ and $\left[\mathrm{Li}_{4}\left(\mathrm{C}_{5} \mathrm{H}_{3} \mathrm{NMeNHSiMe}_{2} \mathrm{O}\right)_{4}\right][1.842(7)$ $\AA$ and $1.580(4)] .^{34}$ In thf medium, the highly polarized but still mainly covalent $\left[\left\{\mathrm{Li}\left(\mu_{3}-\mathrm{ONep}\right)\right\}_{8}\right]$ starting material ${ }^{14}$ is probably responsible for attacking the $\mathrm{Si}-\mathrm{O}$ bond in the silicone grease (Scheme 1, adapted from reference 35). The resulting $\left\{(\mathrm{NepO}) \mathrm{Si}(\mathrm{Me})_{2} \mathrm{O}\right\}^{\delta} \mathrm{Li}^{\delta+}$ fragment then coordinates to two other lithium neopentoxide moieties to form part of the $\left\{\mathrm{VLi}_{3} \mathrm{O}_{4}\right\}$ cubane-like unit. This proposition agrees well with our previous experience with analogous reactions between $\left[\mathrm{V}_{2}(\mu-\mathrm{OR})_{2}(\mathrm{OR})_{6}\right]$ starting materials ( $\mathrm{R}=$ isopropyl or neopentyl) and other, more ionic alkali metal alkoxides (Na, K), where no product of silicone grease degradation has ever been isolated, even in thf solution. This suggests that the significant polarizing character of the lithium cation is relevant for the generation and stabilization of reaction intermediates in these systems.

\section{Complex 2}

There are two independent V-Li complex and two solvent (neopentanol) molecules in the crystal (Figures 4 and S1). One of the complex molecules shows disorder

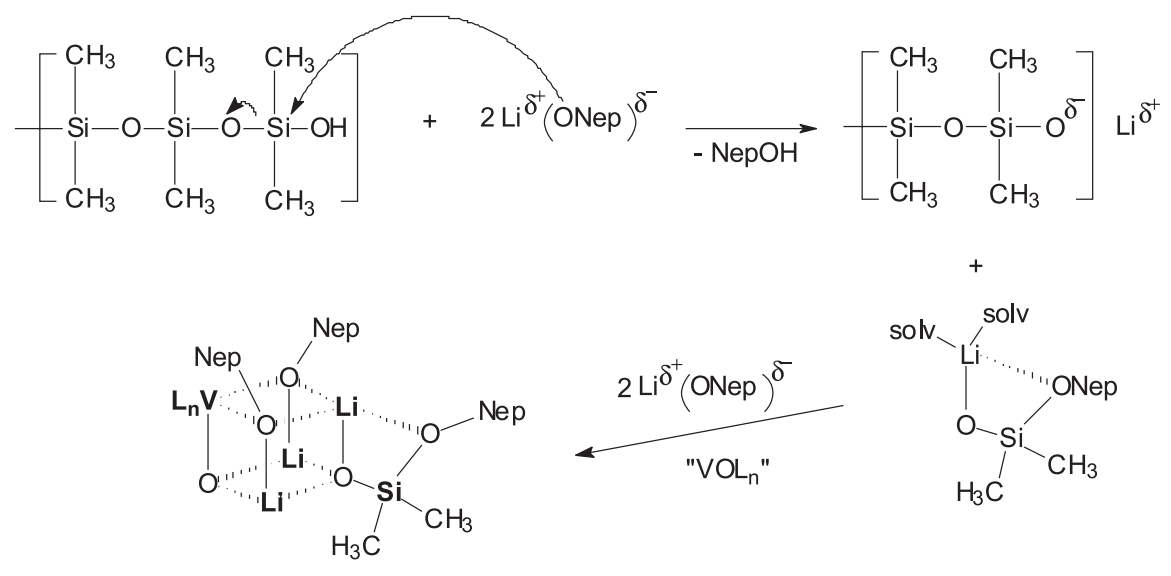

solv = solvent molecules 
in three of its ligands (Figure S1 and additional structure discussion in the Supplementary Information).

The two V-Li molecules have very similar cores, in spite of small differences in bond lengths and angles. Crystallographic data and selected structural parameters are listed in Tables 1, 3 and $\mathrm{S} 2$. The vanadium atoms are five-coordinate, bound by five ONep ligands in trigonal bipyramidal patterns, as shown by the $\mathrm{O}(12)-\mathrm{V}(1)-\mathrm{O}(11)$, $\mathrm{O}(12)-\mathrm{V}(1)-\mathrm{O}(13)$ and $\mathrm{O}(14)-\mathrm{V}(1)-\mathrm{O}(13)$ angles of $171.34(14)^{\circ}, 90.77(13)^{\circ}$ and $119.05(16)^{\circ}$ respectively. Two of these ligands, one in an axial site and one equatorial, form bridging links to the lithium atom, which is also bonded to two thf ligands.

Table 3. Selected molecular dimensions for one of the two independent $\left[\mathrm{V}(\mathrm{ONep})_{3}(\boldsymbol{\mu}-\mathrm{ONep})_{2} \mathrm{Li}(\mathrm{thf})_{2}\right]$ molecules in the crystals of complex $\mathbf{2}$. Additional data are presented in Table S2. Bond lengths are in Ångstroms, angles in degrees. Standard deviations are in parentheses

\begin{tabular}{lccc}
\hline \multicolumn{4}{l}{ Bond lengths involving the vanadium and lithium atoms } \\
\hline $\mathrm{V}(1)-\mathrm{O}(11)$ & $1.968(3)$ & $\mathrm{V}(1)-\mathrm{O}(14)$ & $1.782(3)$ \\
$\mathrm{V}(1)-\mathrm{O}(12)$ & $1.864(3)$ & $\mathrm{V}(1)-\mathrm{O}(15)$ & $1.837(3)$ \\
$\mathrm{V}(1)-\mathrm{O}(13)$ & $1.866(3)$ & $\mathrm{V}(1) \ldots \mathrm{Li}(1)$ & $2.878(9)$ \\
$\mathrm{Li}(1)-\mathrm{O}(11)$ & $1.883(9)$ & $\mathrm{Li}(1)-\mathrm{O}(16)$ & $1.932(10)$ \\
$\mathrm{Li}(1)-\mathrm{O}(13)$ & $1.936(9)$ & $\mathrm{Li}(1)-\mathrm{O}(17)$ & $1.993(10)$ \\
\hline $\mathrm{Bond}$ angles about the vanadium and lithium atoms & \\
\hline $\mathrm{O}(12)-\mathrm{V}(1)-\mathrm{O}(11)$ & $171.34(14)$ & $\mathrm{O}(14)-\mathrm{V}(1)-\mathrm{O}(12)$ & $94.73(14)$ \\
$\mathrm{O}(13)-\mathrm{V}(1)-\mathrm{O}(11)$ & $80.76(13)$ & $\mathrm{O}(15)-\mathrm{V}(1)-\mathrm{O}(12)$ & $91.25(14)$ \\
$\mathrm{O}(14)-\mathrm{V}(1)-\mathrm{O}(11)$ & $91.03(14)$ & $\mathrm{O}(14)-\mathrm{V}(1)-\mathrm{O}(13)$ & $119.05(16)$ \\
$\mathrm{O}(15)-\mathrm{V}(1)-\mathrm{O}(11)$ & $91.59(13)$ & $\mathrm{O}(15)-\mathrm{V}(1)-\mathrm{O}(13)$ & $121.34(14)$ \\
$\mathrm{O}(12)-\mathrm{V}(1)-\mathrm{O}(13)$ & $90.77(13)$ & $\mathrm{O}(14)-\mathrm{V}(1)-\mathrm{O}(15)$ & $119.16(15)$ \\
$\mathrm{O}(11)-\mathrm{Li}(1)-\mathrm{O}(13)$ & $81.2(4)$ & $\mathrm{O}(13)-\mathrm{Li}(1)-\mathrm{O}(17)$ & $119.3(5)$ \\
$\mathrm{O}(11)-\mathrm{Li}(1)-\mathrm{O}(16)$ & $122.1(5)$ & $\mathrm{O}(16)-\mathrm{Li}(1)-\mathrm{O}(17)$ & $107.5(5)$ \\
$\mathrm{O}(11)-\mathrm{Li}(1)-\mathrm{O}(17)$ & $113.8(5)$ & $\mathrm{Li}(1)-\mathrm{O}(11)-\mathrm{V}(1)$ & $96.7(3)$ \\
$\mathrm{O}(16)-\mathrm{Li}(1)-\mathrm{O}(13)$ & $111.6(5)$ & $\mathrm{V}(1)-\mathrm{O}(13)-\mathrm{Li}(1)$ & $98.4(3)$ \\
\hline
\end{tabular}

Angles about the lithium centre range from average values of $81.2(4)^{\circ}$, for $\mathrm{O}(\mu$-ONep $)-\mathrm{Li}-\mathrm{O}(\mu$-ONep $)$, to $124.6(5)^{\circ}$ for $\mathrm{O}(\mu-\mathrm{ONep})-\mathrm{Li}(4)-\mathrm{O}(\mathrm{thf})$, revealing a highly distorted tetrahedral geometry determined by the alkoxide bridges and the bulk of the neopentoxide and thf ligands. The $\mathrm{Li}^{-\mathrm{O}_{\text {(Nep) }}}$ average distances of 1.913(9) $\AA$ and $\mathrm{Li}-\mathrm{O}_{\text {(hff }}$ of 1.963(10) $\AA$ are in agreement with the range observed for the $\left[\left\{\mathrm{Li}\left(\mu_{3}-\mathrm{ONep}\right)\right\}_{8}\right]$ starting material and for solvated lithium alkoxides such as $\left[\left\{\mathrm{Li}\left(\mu_{3} \text {-ONep }\right)\right\}_{4}(\text { thf })_{3}\right] .{ }^{14}$ The average bond lengths of 1.907(3) $\AA$ for $\mathrm{V}-\mu-\mathrm{O}_{\text {(Nep) }}$ and 1.809(7) $\AA$ for terminal $\mathrm{V}-\mathrm{O}_{(\mathrm{Nep})}$ are very close to those observed for the homonuclear species $\left[\mathrm{V}_{2}(\mu-\mathrm{ONep})_{2}(\mathrm{ONep})_{6}\right]$ (2.012(6) $\AA$ for bridging and 1.801(6) $\AA$ for terminal $\mathrm{V}-\mathrm{O}_{(\text {Nep })}$ bonds respectively $)^{15}$ and $\left[\mathrm{V}_{2}\left(\mu-\mathrm{OPr}^{\mathrm{i}}\right)_{2}\left(\mathrm{OPr}^{\mathrm{i}}\right)_{6}\right]$,
2.012(10) $\AA$ and 1.8154(11) $\AA,{ }^{11}$ in accordance with the very similar coordination spheres of the vanadium in the three complexes.

\section{Spectroscopic and magnetochemical analyses}

$\left.{ }^{29} \mathrm{Si}_{\{}{ }^{1} \mathrm{H}\right\}$ Nuclear magnetic resonance (NMR)

A saturated thf solution of product $\mathbf{1}$ containing a few drops of toluene- $d_{8}$ was analyzed by ${ }^{29} \mathrm{Si}\left\{{ }^{1} \mathrm{H}\right\}$ NMR in order to confirm the presence of silanolate groups; results are summarized in Figure 5. The sample of $\mathbf{1}$ produced only one, well defined resonance signal at $\delta=-19.2 \mathrm{ppm}$ (Figure 5b). The silicone grease, dissolved in the same solvent mixture, gave a clean signal at $-21.9 \mathrm{ppm}$, which is easily distinguished from that presented by 1 (Figures $5 \mathrm{a}$ and $5 \mathrm{c}$ ). The position of the ${ }^{29} \mathrm{Si}$ resonance signal of $\mathbf{1}$ at a higher frequency value as compared to the grease is compatible with the binding of each equivalent $\left\{\mathrm{OSi}(\mathrm{Me})_{2}(\mathrm{ONep})\right\}^{-}$group in $\mathbf{1}$ to three $\mathrm{Li}$ sites (Figure 3), which act as electron-withdrawing groups and increase the ${ }^{29} \mathrm{Si}$ NMR chemical shift.

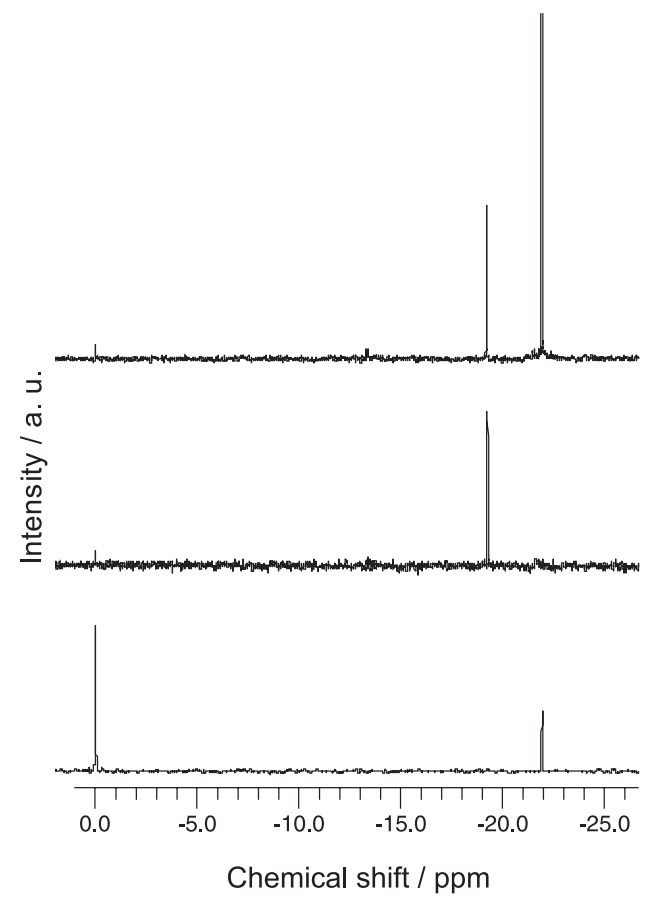

(c)

(b)

(a)

Figure 5. ${ }^{29} \mathrm{Si}\left\{{ }^{1} \mathrm{H}\right\}$ NMR spectra in non-deuterated thf solution, with toluene- $d_{8}$ (lock signal) and tetramethylsilane (chemical shift reference at 0.0 ppm): (a) solvent mixture + silicone grease; (b) saturated solution of complex $\mathbf{1}$; (c) saturated solution of complex $\mathbf{1}$ with added silicone grease.

Electron paramagnetic resonance $(E P R)$ and magnetic moment measurements

The solid state EPR spectrum of powdered $\mathbf{1}$ at $77 \mathrm{~K}$ (Figure 6) exhibits a broad line with partially resolved hyperfine features, centred at $c a .346 \mathrm{mT}$, that indicates magnetic interaction between the vanadium sites in the 
solid $\left({ }^{51} \mathrm{~V}, I=7 / 2\right)$. This is in accordance with the total effective magnetic moment of $5.66 \beta_{\mathrm{e}}$ determined for $\mathbf{1}$ in the solid state at $300 \mathrm{~K}$, significantly lower than the spin-only value for a system with 4 vanadium(IV) and 2 vanadium(III) independent centres ( $\mathrm{S}=4, \mu_{\mathrm{eff}}=8.94 \beta_{\mathrm{e}}$ ). These measurements suggest a strong antiferromagnetic interaction among the vanadium centres, possibly by a superexchange mechanism involving the bridging oxo groups $\mathrm{O}(14), \mathrm{O}(15)$ and $\mathrm{O}(23)$ (Figures 2 and 3). The very low solubility of $\mathbf{1}$ in common organic solvents so far precluded detailed solution studies.

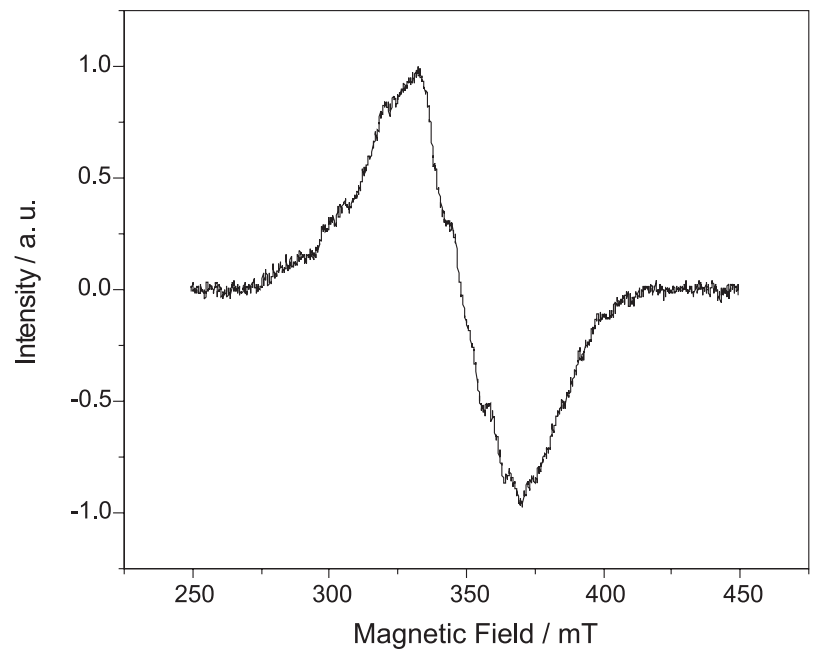

Figure 6. Solid state EPR (powder) spectrum of $\left[\mathrm{V}_{6} \mathrm{Li}_{10} \mathrm{O}_{8}(\mathrm{ONep})_{14}\right.$ $\left.\left\{\mathrm{OSi}(\mathrm{Me})_{2}(\mathrm{ONep})\right\}_{2}\right] \cdot \mathrm{C}_{6} \mathrm{H}_{14}$ (complex 1). Microwave frequency: $9.441 \mathrm{GHz}$; temperature: $77 \mathrm{~K}$.

The $77 \mathrm{~K}$ powder (solid state) EPR spectrum of 2 (Figure 7) shows a dominant eight-line parallel hyperfine signature of ${ }^{51} \mathrm{~V}$ in the +IV oxidation state, $d^{1}$. The spectrum was simulated using Gaussian lineshapes corrected by small magnetic field and hyperfine strains. Collinear $g$ and $A$ rhombic tensors were used (Table 4). Magnetic moment determinations carried out for solid 2 at $300 \mathrm{~K}$ gave an average $\mu_{\text {eff }}$ value of $1.79 \beta_{\mathrm{e}}$, very close to the spin-only figure $\left(1.73 \beta_{\mathrm{e}}\right)$, corroborating the absence of significant orbital contributions to the susceptibility and of magnetic interactions involving the vanadium centres in the solid.

The $77 \mathrm{~K}$ frozen solution EPR spectrum of $\mathbf{2}$ (Figure 8) shows the remarkable features of vanadium(IV) $(\mathrm{S}=1 / 2)$

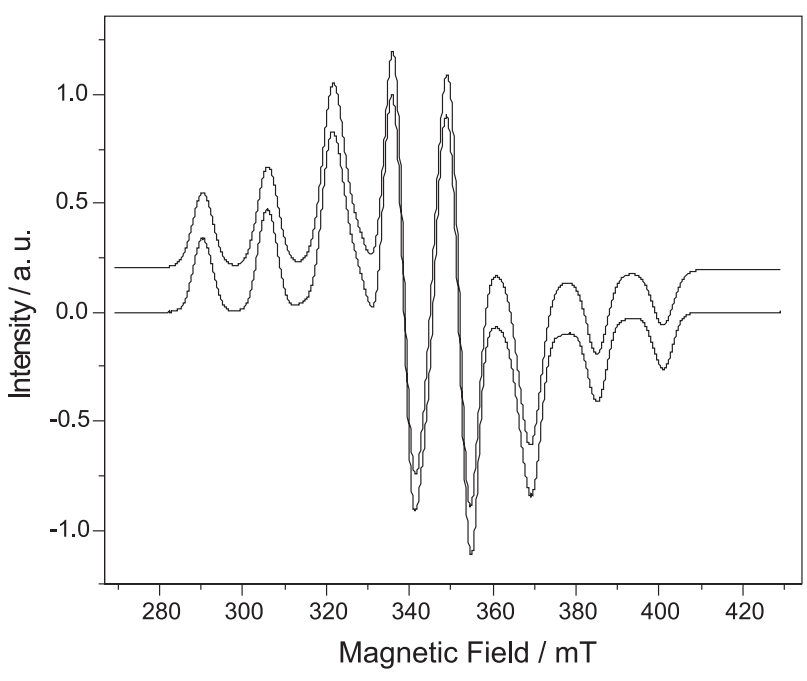

Figure 7. Experimental (thick line) and simulated solid (powder) EPR spectra of $\left[\mathrm{V}(\mathrm{ONep})_{3}(\mu-\mathrm{ONep})_{2} \mathrm{Li}(\mathrm{thf})_{2}\right] \cdot \mathrm{NepOH}(\mathrm{complex} 2)$. Microwave frequency $9.437 \mathrm{GHz}$; temperature $77 \mathrm{~K}$.

along with almost central perpendicular splittings. The simulation parameters are in very good agreement with those of the powder spectrum (Table 4), strongly suggesting that the binuclear aggregation revealed for $\mathbf{2}$ in the solid state (Figure 4) is kept in thf solution. The small discrepancies between the EPR parameters of the powdered solid and the frozen solution come from line position uncertainties due to molecular strains, as well as from electron dipolar line broadening present in the higher spin concentration solid sample, which leads to larger line widths. In accordance to the above, powdered solid lineshapes tend to best fit to a convolution of Gaussian/Lorentzian (0.75/0.25) lineshapes. Despite at first glance the symmetry at the vanadium site could seem axial $\left(D_{3 h}\right)$, bond lengths about $\mathrm{O}(13), \mathrm{O}(14)$ and $\mathrm{O}(15)$ are different, leading to the rhombic tensors presented in Table 4. Moreover, the two axial bonds $\mathrm{V}(1)-\mathrm{O}(11)$ and $\mathrm{V}(1)-\mathrm{O}(12)$ are not quite colinear, with an angle of $171.34(14)^{\circ}$ (Table 3 ).

The room temperature solution EPR spectrum (Figure 9) also displays an eight-line pattern. The particular overall shape is due to an interference between the line width $l w$ and the isotropic hyperfine coupling $A_{\text {iso }}$. The ratio $l w / A_{\text {iso }}$ can lead from a two-line spectrum, when $l w>A_{\text {iso }}$, to the very well known octet when $l w<A_{\text {iso }}{ }^{36}$ The linewidth (Lorentzian line shape) observed for $\mathbf{2}$ is mostly dictated by

Table 4. Gyromagnetic and hyperfine simulated couplings for complex 2 at $77 \mathrm{~K}$

\begin{tabular}{lccccccccc}
\hline \multirow{2}{*}{ Sample } & \multicolumn{3}{c}{ Hyperfine couplings ${ }^{(\mathrm{a})} / \mathrm{MHz}$} & \multicolumn{3}{c}{ Gyromagnetic couplings ${ }^{(\mathrm{b})}$} & \multicolumn{2}{c}{ Line width/mT } \\
& $A_{\mathrm{x}}$ & $A_{\mathrm{y}}$ & $A_{\mathrm{z}}$ & $A_{\text {iso }}$ & $g_{\mathrm{x}}$ & $g_{\mathrm{y}}$ & $g_{\mathrm{z}}$ & $g_{\mathrm{av}}$ & \\
\hline Powdered solid & 94.860 & 115.41 & 430.46 & 213.58 & 1.9756 & 1.9281 & 1.9502 & 1.9513 & 6.325 \\
Frozen thf solution & 97.393 & 122.41 & 432.06 & 217.29 & 1.9773 & 1.9247 & 1.9490 & 1.9503 & 0.955 \\
\hline
\end{tabular}

${ }^{(a)} A_{\text {iso }}=\left(A_{\mathrm{x}}+A_{\mathrm{y}}+A_{\mathrm{z}}\right) / 3$ and $^{(\mathrm{b})} g_{\text {av }}=\left(g_{\mathrm{x}}+g_{\mathrm{y}}+g_{\mathrm{z}}\right) / 3$. 


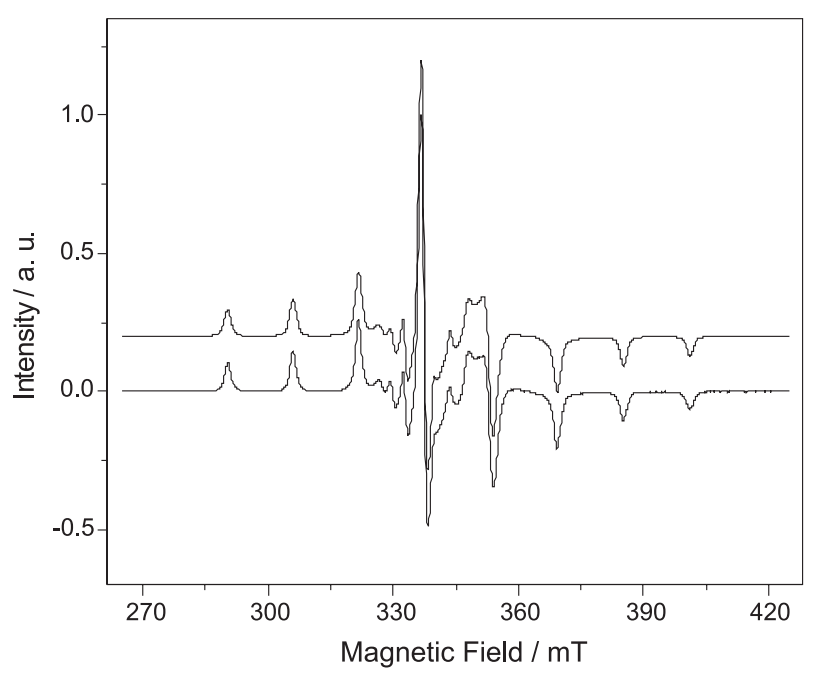

Figure 8. Experimental (thick line) and simulated frozen solution EPR spectra of $\left[\mathrm{V}(\mathrm{ONep})_{3}(\boldsymbol{\mu}-\mathrm{ONep})_{2} \mathrm{Li}(\mathrm{thf})_{2}\right] \mathrm{NepOH}($ complex 2$)$. Microwave frequency: $9.434 \mathrm{GHz}$; temperature: $77 \mathrm{~K}$; solvent: tetrahydrofuran.

a fast motion tumbling regime, with a solution correlation time $\left(\tau_{\mathrm{c}}\right)$ of $2.29 \times 10^{-11} \mathrm{~s}$, in agreement with equivalent systems (Table 5). ${ }^{37}$ The clear correspondence between the simulated $A_{\text {iso }}$ and $\mathrm{g}_{\mathrm{av}}$ parameters presented in Tables 4 and 5 is noteworthy, as far as the $77 \mathrm{~K}$ (solid state and frozen solution) and room temperature systems are concerned. This again reinforces the maintenance of the binuclear structure of $\mathbf{2}$ after dissolution in thf.

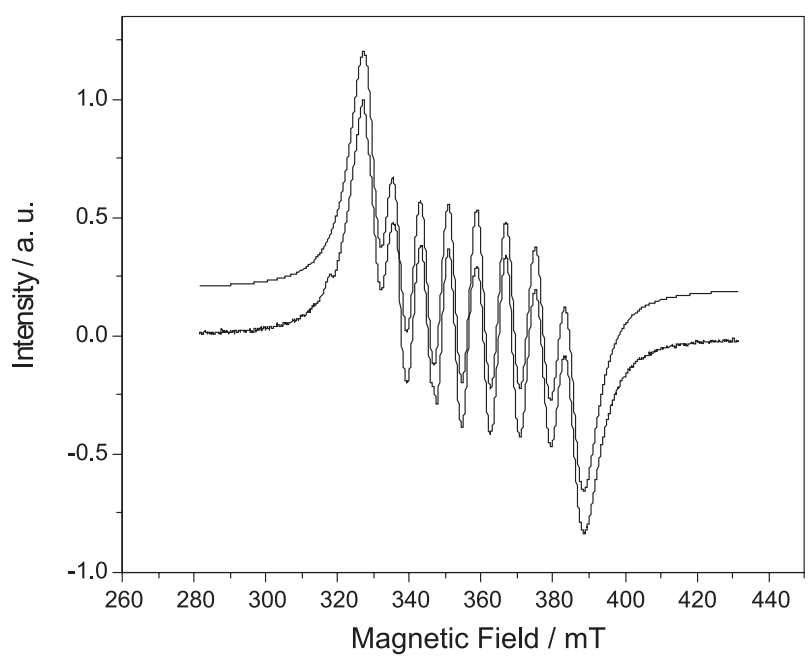

Figure 9. Experimental (thick line) and simulated solution EPR spectra of $\mathbf{2}$ in the fast motion regime. Microwave frequency: $9.769 \mathrm{GHz}$; room temperature; solvent: tetrahydrofuran.

\section{Infrared spectroscopy}

Figure $\mathrm{S} 2$ shows a comparison of the infrared spectra of the vanadium starting material, $\left[\mathrm{V}_{2}(\mu-\mathrm{ONep})_{2}(\mathrm{ONep})_{6}\right]$, and of the two $\mathrm{V} / \mathrm{Li}$ compounds described in this work. The FTIR spectra of $\mathbf{1}$ and $\mathbf{2}$ present strong absorptions in the $1385-1360 \mathrm{~cm}^{-1}$ range, assignable to skeletal vibrations of the neopentyl group. Strong bands at $c a .1080,1060$ and $1020 \mathrm{~cm}^{-1}$, and a weak band at $c a .930 \mathrm{~cm}^{-1}$, may be attributed to C-O stretching frequencies. ${ }^{14,38}$ The spectra also exhibit absorptions between 650 and $460 \mathrm{~cm}^{-1}$, which are attributed to $\mathrm{V}-\mathrm{O}$ stretches. ${ }^{31,38}$

\section{Chemical reactivity leading to the formation of products} 1 and $\mathbf{2}$

Intriguingly, complex $\mathbf{1}$ appears to be a mixed-valence vanadium(III)/vanadium(IV) species, as required by charge balance arguments, considering the presence of ten $\mathrm{Li}^{+}$centres and eight oxo, fourteen neopentoxide and two $\left\{\mathrm{OSi}(\mathrm{Me})_{2}(\mathrm{ONep})\right\}^{-}$ligands. This demands four vanadium(IV) and two vanadium(III) centres; any other combination would lead to even lower oxidation state vanadium, which is unlikely in this hard-donor environment. As the vanadium starting material, $\left[\mathrm{V}_{2}(\mu-\mathrm{ONep})_{2}(\mathrm{ONep})_{6}\right]$, contains only vanadium(IV), this implies the occurrence of a reduction reaction giving vanadium(III), tentatively associated, in 1, with the unique, distorted octahedral $\mathrm{V}$ (3) centre (Figures 2 and 3). The five-coordinate V(1) and $\mathrm{V}(2)$, in their turn, are supposed to be in the +IV oxidation state. These assignments are based on the inversion symmetry of the molecular assembly and the most common coordination numbers of vanadium(III) and (IV) in $O$-donor environments. ${ }^{39}$ The possibility of an oxidation state intermediate between $+\mathrm{III}$ and $+\mathrm{IV}$ must also be considered, although the different symmetries of the vanadium sites, $\mathrm{V}(1) \approx \mathrm{V}(2) \neq \mathrm{V}(3)$, favour more localized valencies..$^{40}$ On the other hand, the crystal field strengths are similar, the difference in bond lengths about the transition metal centres is small and the bridging oxides lead to short V …V distances, so a degree of delocalization, corresponding to Robin and Day's intervalence class II, can be expected. The magnetic properties of $\mathbf{1}$ also give support to this hypothesis, and further studies are both necessary

Table 5. Fast motion regime gyromagnetic and hyperfine simulated couplings for complex $\mathbf{2}$ in thf solution at room temperature

\begin{tabular}{|c|c|c|c|c|c|c|c|}
\hline \multicolumn{3}{|c|}{ Hyperfine couplings ${ }^{\text {(a) }} / \mathrm{MHz}$} & \multicolumn{3}{|c|}{ Gyromagnetic couplings ${ }^{(\mathrm{b})}$} & \multirow{2}{*}{$\frac{\text { Tumbling correlation time }\left(\tau_{c}\right) / \mathrm{s}}{2.285 \times 10^{-11}}$} & \multirow{2}{*}{$\begin{array}{c}\text { Line width / } \mathrm{mT} \\
8.240\end{array}$} \\
\hline $\begin{array}{c}A_{\perp} \\
65.459\end{array}$ & $\begin{array}{c}A_{\|} \\
518.78\end{array}$ & $\begin{array}{c}A_{\text {iso }} \\
216.57\end{array}$ & $\begin{array}{c}g_{\perp} \\
1.9554\end{array}$ & $\begin{array}{c}g_{\|} \\
1.9372\end{array}$ & $\begin{array}{c}g_{\mathrm{av}} \\
1.9493\end{array}$ & & \\
\hline
\end{tabular}

${ }^{\text {(a) }} A_{\text {iso }}=\left(2 A_{\perp}+A_{/ /}\right) / 3$ and ${ }^{\text {(b) }} g_{\text {av }}=\left(2 g_{\perp}+g_{/ /}\right) / 3$. 
and justified in this case, as mixed-valence compounds can show interesting nonlinear optical properties, besides other applications. ${ }^{41}$

Another relevant structural feature of $\mathbf{1}$ is the presence of the eight oxo $\left(\mathrm{O}^{2-}\right)$ ligands, which do not appear in $\mathbf{2}$ or in the starting materials. The origin of these bridging groups could be in the general tendency of ether elimination by high valence transition metal alkoxides ${ }^{42}$ such as the ones formed by vanadium(IV)/(V):

$$
2 \mathrm{~L}_{\mathrm{n}} \mathrm{MOR} \rightarrow\left(\mathrm{L}_{\mathrm{n}} \mathrm{M}\right)_{2} \mathrm{O}+\mathrm{R}_{2} \mathrm{O}
$$

and/or in the accidental activation of the silicon grease by the vanadium and lithium precursors, as discussed below.

A number of works have reported the occurrence of redox and/or fragmentation processes in highly reactive systems involving metal alkoxides, Grignard reagents and metal amides. ${ }^{43-45}$ Representative reports include (i) $\alpha$ - or $\beta$-hydride transfer from alkali metal alkoxides or Grignard compounds to organic electrophiles, ${ }^{44}$ (ii) ether/ketone elimination ${ }^{46}$ and alkyl radical departure from transition metal alkoxides ${ }^{47}$ and (iii) metal disproportionation. ${ }^{45}$ In case (ii), events of transition metal reduction, alkoxide C-O bond homolysis and oxo group formation (both terminal and bridging) are either concomitant or part of further rearrangements in the reaction mixtures.

The mechanism of formation of $\mathbf{1}$, taking into account both the presence of the oxo groups and vanadium(III), is not yet known. According to Mayer ${ }^{43}$ in general, a ligand $\mathrm{C}-\mathrm{O}$ or $\mathrm{O}-\mathrm{H}$ bond should be considered activated for cleavage - leaving metal-bound oxo groups - in all systems where a related metal oxide is accessible. This is surely the case for the reaction mixtures employed in this work. Conditions as those favouring the occurrence of metal reduction are also present. This suggests that vanadium(III) and oxo groups should be formed - not necessarily in the same proportions - in both reaction media described here. However, the distinct and yet reproducible character of the reactions that give $\mathbf{1}$ and $\mathbf{2}$ suggest that the involvement of the grease - the main difference between the two procedures - has more significant consequences than the ones tentatively illustrated in Scheme 1. As no trivial redox mechanism involving (poly)alkylsiloxanes as metal reducing agents can be easily envisaged in our reaction conditions, the activation of the silicone chains and the consequent formation of the silanolate groups, $\left\{\mathrm{OSi}\left(\mathrm{Me}_{2}\right)(\mathrm{ONep})\right\}^{-}$, may actually be key thermodynamic factors that determine the stabilization of $\mathbf{1}$ and drive the equilibrium position in its favour. This apparently prevents the formation of $\mathbf{2}$ in the presence of the grease. Further studies are needed in order to clarify this.

\section{Conclusions}

The attempt to prepare " $\mathrm{LiV}(\mathrm{OR})_{5}$ "-type compounds from a non-oxo vanadium(IV) starting material and "Li(OR)" ( $\mathrm{R}=$ neopentyl) gave two products, complexes 1 and $\mathbf{2}$, with distinctive structural features. While $\mathbf{2}$ presents a simple binuclear V-Li composition both in thf solution and in the solid state, product $\mathbf{1}$ is an unexpected mixedvalence vanadium-lithium polynuclear aggregate whose formation follows the accidental solubilization of silicone grease into the reaction media. The reproducibility and high yield of both preparations are promising features to facilitate further investigation of reaction mechanisms and possible synthetic, electrochemical, optical and catalytic applications of the two compounds. Both products are potential precursors for mixed-metal oxides. Complex 1 may also be useful for the preparation of ternary $\mathrm{Si}-\mathrm{V}-\mathrm{Li}$ composites and for the oxo-functionalization of organic substrates, a relevant reaction in academic and industrial research.

\section{Supplementary Information}

Supplementary data (additional structure description for complex 2, Tables S1-S2 and Figures S1-S2) are available free of charge at http://jbcs.sbq.org.br, as a PDF file.

Crystallographic data (excluding structure factors) have been deposited with the Cambridge Crystallographic Data Centre (CCDC) as supplementary material. Copies can be obtained free of charge via www.ccdc. cam.ac.uk/conts/retrieving.html or from the CCDC, 12 Union Road, Cambridge CB2 1EZ, UK (fax: +44 1223 336033 or e-mail: deposit@ccdc.cam.ac.uk), quoting the deposition numbers CCDC 704159 (complex 1) and 704158 (complex 2).

\section{Acknowledgments}

We acknowledge the use of the Chemical Database Service at Daresbury (Cambridge Crystallographic Data Centre, CCDC) and financial support from the Conselho Nacional de Desenvolvimento Científico e Tecnológico (CNPq), Coordenação de Aperfeiçoamento de Pessoal de Nível Superior (CAPES), Financiadora de Estudos e Projetos (FINEP/MCT/CT-INFRA), Fundação Araucária de Apoio ao Desenvolvimento Científico e Tecnológico do Paraná and Universidade Federal do Paraná (UFPR). D. M. Reis, K. C. M. Westrup, G. G. Nunes, A. Barison and R. R. Ribeiro thank CNPq, CAPES and Fundação Araucária for scholarships. 


\section{References}

1. Rosenthal, E. C. E.; Cui, H. L.; Hummert M.; Inorg. Chem. Commun. 2008, 11, 918; Khan, M. I.; Quen, Q.; Goshorn, D. P.; Zubieta, J.; Inorg. Chem. 1993, 32, 672; Rosenthal, E. C. E.; Cui, H. L.; Koch, J.; Gaede, P. E.; Hummert, M.; Dechert, S.; Dalton Trans. 2005, 3108.

2. Ivanova, T.; Harizanova, A.; Mater. Res. Bull. 2005, 40, 411; Turhan, I.; Tepehan, F. Z.; Tepehan, G. G.; J. Mater. Sci. 2005, 40, 1359; Vuk, A. S.; Orel, B.; Drazik, G.; Decker, F.; Colomban, P.; J. Sol-Gel Sci. Technol. 2002, 23, 165; Bencic, S.; Orel, B.; Surca, A.; Stangar, U. L.; Sol. Energy 2000, 68, 499.

3. Sharma, N.; Meena, T. M.; Kumar V.; Chaudhry, S. C.; Indian J. Chem., Sect. A: Inorg., Bio-inorg., Phys., Theor., Anal. Chem. 2008, 685; Beteille, F.; Mazerolles, L.; Livage, J.; Mater. Res. Bull. 1999, 34, 2177; Speck, K. R.; Hu, H. S-W.; Sherwin M. E.; Potember, R. S.; Thin Solid Films 1988, 165, 317.

4. Foulon, G.; Foulon, J. D.; Hovnanian, N.; Polyhedron 1993, $12,2507$.

5. Tidmarsh, I. S.; Brearley, P. R.; Scales, E.; Wolowska, J.; Sorace, L.; Caneschi, A.; Laye, R. H.; McInnes E. J. L.; Inorg. Chem. 2007, 9743; Hagen, H.; Reinoso, S.; Reijerse, E. J.; van Faassen, E. E.; Lutz, M.; Spek, A. L.; van Koten, G.; Z. Anorg. Allg. Chem. 2004, 630, 2097.

6. Boyle, T. J.; Alam T. M.; Tafoya, C. J.; Mechenbier, E. R.; Inorg. Chem. 1999, 38, 2422; Hampden-Smith, M. J.; Williams, D. S.; Rheingold, A. L.; Inorg. Chem. 1990, 29, 4076.

7. Bradley, D. C.; Multani, R. K.; Wardlaw, W.; J. Chem. Soc. 1958, 4647.

8. Nunes, G. G.; Friedermann, G. R.; Herbst, M. H.; Barthem, R. B.; Vugman, N. V.; Barclay J. E.; Evans, D. J.; Hitchcock, P. B.; Leigh, G. J.; Sá, E. L.; Soares, J. F.; Inorg. Chem. Commun. 2003, 6, 1278; Nunes, G. G.; Friedermann, G. R.; Hitchcock, P. B.; de Sá, E. L.; Soares, J. F.; Inorg. Chem. Acta 2006, 359 , 1435.

9. Boyle, T. J.; Gallegos, J. J.; Pedrotty, D. M.; Mechenbier, E. R.; Scott, B. L.; J. Coord. Chem. 1999, 47, 155.

10. Albaric, L.; Hovnanian, N.; Julbe, A.; Volle, G.; Polyhedron 2001, 20, 2261.

11. Nunes, G. G.; Friedermann, G. R.; dos Santos, J. L. B.; Herbst, M. H.; Vugman, N. V.; Hitchcock, P. B.; Leigh, G. J.; Sá, E. L.; da Cunha, C. J.; Soares, J. F.; Inorg. Chem. Commun. 2005, 8 , 83.

12. Veith, M.; Mathur, S.; Mathur, C.; Polyhedron 1998, 17, 689; Veith, M.; Mathur, S.; Huch, V.; J. Am. Chem. Soc. 1996, 118, 903.

13. Wang, Y.; Cao, G. Z.; Chem. Mater. 2006, 18, 2787; Holland, G. P.; Huguenin, F.; Torresi, R.; Buttry, D. A.; J. Electrochem. Soc. 2003, 150, A721; Scarminio, J.; Catarini, P. R.; Urbano, A.; Gelamo, R. V.; Rouxinol, F. P.; de Moraes, M. A. B.; J. Braz. Chem. Soc. 2008, 19, 788.
14. Boyle, T. J.; Alam, T. M.; Peters, K. P.; Rodriguez, M. A.; Inorg. Chem. 2001, 40, 6281; Manzer, L. E.; Inorg. Synth. 1982, 21, 138.

15. Westrup, K. C. M.; Reis, D. M.; Nunes, G. G.; Hitchcock, P. B.; Soares, J. F.; Cambridge Structural Database, 2008, deposition number CCDC 705491.

16. Haiduc, I.; Organometallics 2004, 23, 3; Steiner, A.; Lawson, G. T.; Walfort, B.; Leusser, D.; Stalke, D.; J. Chem. Soc., Dalton Trans. 2001, 219; Harvey, S.; Lappert, M. F.; Raston, C. L.; Skelton, B. W.; Srivastava, G.; White, A. H.; J. Chem. Soc., Chem. Commun., 1988, 1216; Lennartson, A., Hakansson, M.; Acta Crystallogr., Sect. C: Cryst. Struct. Commun. 2008, 64, m8.

17. Bottomley, F.; Karslioglut, S.; Organometallics 1992, 11, 326; Edwards, D. A.; Harker, R. M.; Mahon, M. F.; Molloy, K. C.; J. Chem. Soc., Dalton Trans. 1997, 3509; Ackermann, H.; Weller, F.; Dehnicke, K.; Z. Naturforsch., Teil B 2000, 55b, 448.

18. Perrin, D. D.; Armarego, W. L. F.; Purification of Laboratory Chemicals, $3^{\text {rd }}$ ed., Butterworth-Heinemann: Oxford, 1988.

19. O'Connor, C. J.; Prog. Inorg. Chem. 1982, 29, 203; Friedermann, G. R.; Nunes, G. G.; Soares, J. F.; Quim. Nova 2005, 28, 340.

20. Stoll, S.; Schweiger A.; J. Magn. Reson. 2006, 178, 42.

21. Haaland, A.; Rypdal, K.; Volden, H. V.; Andersen, A. R; J. Chem. Soc., Dalton Trans. 1992, 891.

22. Programs CrysAlis-CCD and -RED, Oxford Diffraction Ltd., Abingdon, UK, 2005.

23. Sheldrick, G. M.; Acta Cryst. 2008, A64, 112.

24. International Tables for X-ray Crystallography, Kluwer Academic Publishers: Dordrecht, 1992, vol. C, pp. 500, 219 and 193.

25. Farrugia, L. J.; J. Appl. Cryst. 1999, 32, 837; Farrugia, L. J.; J. Appl. Cryst. 1997, 30, 565.

26. Goel, S. C.; Hollingsworth, J. A.; Beatty, A. M.; Robinson, K. D.; Buhro, W. E.; Polyhedron 1998, 17, 781.

27. Morgenstern, B.; Kutzky, B.; Neis, C.; Stucky, S.; Hegetschweiler, K.; Garribba, E.; Micera, G.; Inorg. Chem. 2007, 46, 3903; Morgenstern, B.; Steinhauser, S.; Hegetschweiler, K.; Garribba, E.; Micera, G.; Sanna, D.; Nagy, L.; Inorg. Chem. 2004, 43, 3116; Burger, J.; Gack, C.; Klüfers, P.; Angew. Chem., Int. Ed. 1995, 34, 2647; Piarulli, U.; Williams, D. N.; Floriani, C.; Gervasio, G.; Viterbo, D.; J. Chem. Soc., Chem. Commun. 1994, 1409; Alyea, E. C.; Bradley, D. C.; J. Chem. Soc. (A) 1969, 2330.

28. Reis, D. M.; Nunes, G. G.; Sá, E. L.; Friedermann, G. R.; Mangrich, A. S.; Evans, D. E.; Hitchcock, P. B.; Leigh G. J.; Soares, J. F.; New J. Chem. 2004, 28, 1168.

29. O'Keefe, B. J.; Monnier, S. M.; Hillmyer, M. A.; Tolman, W. B.; J. Am. Chem. Soc. 2001, 123, 339; Veith, M.; Gratz, F.; Huch, V.; Gutlich, P.; Ensling, A.; Z. Anorg. Allg. Chem. 2004, 630, 2329; Chae, H. K.; Hwang, C.; Dong, Y.; Yun H.; Jang, H. G.; Chem. Lett. 2000, 992; Hegetschweiler, K.; Schmalle, H. W.; Streit, H. M.; Gramlich, V.; Hund H-U.; Erni, I.; Inorg. Chem. 1992, 31, 1299. 
30. Bradley, D. C.; Chudzynska, H.; Frigo, D. M.; Hammond, M. E.; Hursthouse, M. B.; Mazid, M. A.; Polyhedron 1990, 9, 719; Poncelet, O.; Sartain, W. J.; Hubert-Pfalzgraf, L. G.; Folting K.; Caulton K. G.; Inorg. Chem. 1989, 28, 263; Daniele, S.; Hubert-Pfalzgraf, L. G.; Hitchcock P. B.; Lappert, M. F.; Inorg. Chem. Commun. 2000, 3, 218; Westin, G.; Kritikos, M.; Wijk, M.; J. Solid State Chem. 1998, 141, 168; Hubert-Pfalzgraf, L. G.; Daniele, S.; Bennaceur, A.; Daran, J. C.; Vaissermann, J.; Polyhedron 1997, 16, 1223.

31. Khan, M. I.; Chen, Q.; Goshorn, D. P.; Hope, H.; Parkin, S.; Zubieta, J.; J. Am. Chem. Soc. 1992, 114, 3341; Khan, M. I.; Chen, Q.; Hope, H.; Parkin, S.; O’Connor, C. J.; Zubieta, J.; Inorg. Chem. 1993, 32, 2929; Kessler, V. G.; Seisenbaeva, G.A.; Inorg. Chem. Commun. 2000, 3, 203; Daniel, C.; Hartl, H.; J. Am. Chem. Soc. 2005, 127, 13978.

32. Lam, A. W-H.; Wong, W-T.; Wen, G.; Zhang, X-X.; Gao, S.; New J. Chem. 2001, 25, 531; Shchegolikhina, O. I.; Pozdniakova, Yu. A.; Lindeman, S. V.; Zhdanov, A. A.; Psaro, R.; Ugo, R.; Gavioli, G.; Battistuzzi, R.; Borsari, M.; Rüffer, T.; Zucchi, C.; Palyi, G.; J. Organomet. Chem. 1996, 514, 29.

33. Wilkinson, G.; Gillard R. D.; McCleverty, J. A., eds. In Comprehensive Coordination Chemistry, Pergamon: Oxford, 1987, vol. 2; Nöth, H.; Seifert, T.; Eur. J. Inorg. Chem. 2002, 602.

34. Jones, C.; Junk, P. C.; Leary, S. G.; Smithies, N. A.; J. Chem. Soc., Dalton Trans. 2000, 3186.

35. Jones, R. A.; Koschmieder, S. U.; Atwood, J. L.; Bott, S. G.; J. Chem. Soc., Chem. Commun. 1992, 726.

36. Mabbs, F. E.; Chem. Soc. Rev. 1993, 22, 313.

37. Campbell, R. F.; Freed, J. H.; J. Phys. Chem. 1980, 84, 2668.
38. Barraclough, C. G.; Bradley, D. C.; Lewis J.; Thomas, I. M.; J. Chem. Soc. 1961, 2601; Bradley, D. C.; Mehrotra, R. C.; Gaur, D. P.; Metal Alkoxides, Academic Press: London, 1978; Nakamoto, K.; Infrared and Raman Spectra of Inorganic and Coordination Compounds, $5^{\text {th }}$ ed., John Wiley \& Sons: New York, 1997, part B.

39. Crans, D. C.; Pure Appl. Chem. 2005, 77, 1497.

40. Robin, M.B.; Day, P.; Adv. Inorg. Chem. Radiochem. 1967, 10, 247.

41. Triest, M.; Davis, M. J.; Reber, C.; New J. Chem. 1999, 23, 425.

42. Bradley, D. C.; Mehrotra, R.; Rothwell, I.; Singh, A.; Alkoxo and Aryloxo Derivatives of Metals, Academic Press: San Diego, 2001.

43. Mayer, J. M.; Polyhedron, 1995, 14, 3273; Turova, N. Ya.; Russ. Chem. Rev. 2004, 73, 1041.

44. Linderman, R. J.; Lonikar, M. S.; J. Org. Chem. 1988, 53, 6013; Sokeirik, Y. S.; Sato, K.; Omote, M.; Ando, A.; Kumadaki, I.; Tetrahedron Lett. 2006, 47, 2821.

45. Choukroun, R.; Moumboko, P.; Chevalier, S.; Etienne, M.; Donnadieu, B.; Angew. Chem. Int. Ed. 1998, 37, 3169.

46. Kessler, V. G.; Shevelkov, A. V.; Bengtsson-Kloo, L. A.; Polyhedron 1998, 17, 965; Niederberger, M.; Garnweitner, G.; Pinna, N.; Néri, G.; Prog. Solid State Chem. 2005, 33, 59.

47. Peters, J. C.; Johnson, A. R.; Odom, A. L.; Wanandi, P. W.; Davis, W. M.; Cummins, C. C.; J. Am. Chem. Soc. 1996, 118 , 10175; Crevier, T. J.; Mayer, J. M.; J. Am. Chem. Soc. 1997, 119,8485 .

Received: October 25, 2008 Web Release Date: March 20, 2009 


\section{Vanadium-Lithium Alkoxides: Synthesis, Structure, Spectroscopic Characterisation and Accidental Degradation of Silicone Grease}

Dayane M. Reis, ${ }^{a}$ Kátia Cristina M. Westrup, ${ }^{a}$ Giovana G. Nunes, ${ }^{a}$ Andersson Barison, ${ }^{a}$ Ronny R. Ribeiro, ${ }^{a}$ Eduardo L. de Sá, ${ }^{a}$ David L. Hughes ${ }^{b}$ and Jaísa F. Soares ${ }^{*, a}$

${ }^{a}$ Departamento de Química, Universidade Federal do Paraná, Centro Politécnico, 81530-900, Curitiba-PR, Brazil ${ }^{b}$ School of Chemical Sciences \& Pharmacy, University of East Anglia, Norwich NR4 7TJ, UK

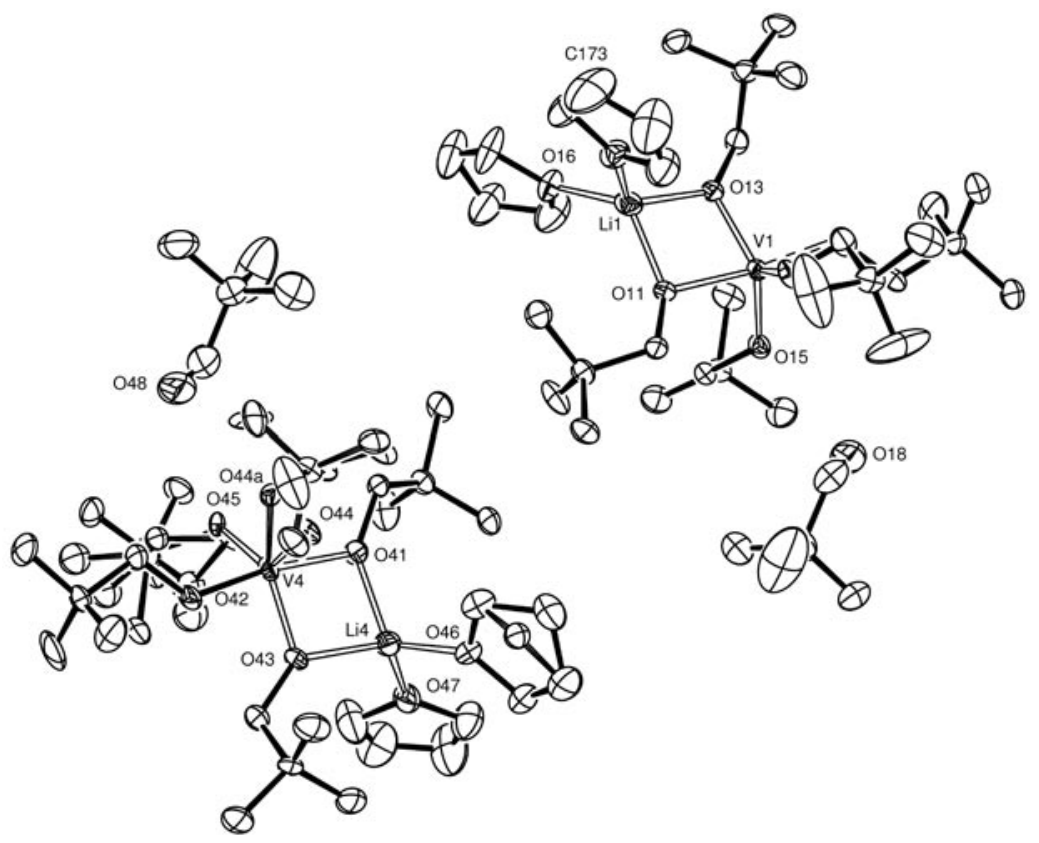

Figure S1. View of the asymmetric unit of $\left[\mathrm{V}(\mathrm{ONep})_{3}(\mu-\mathrm{ONep})_{2} \mathrm{Li}(\mathrm{thf})_{2}\right] \cdot \mathrm{NepOH}(\mathbf{2})$. Hydrogen atoms have been omitted for clarity. Thermal ellipsoids are drawn at the $50 \%$ probability level. 


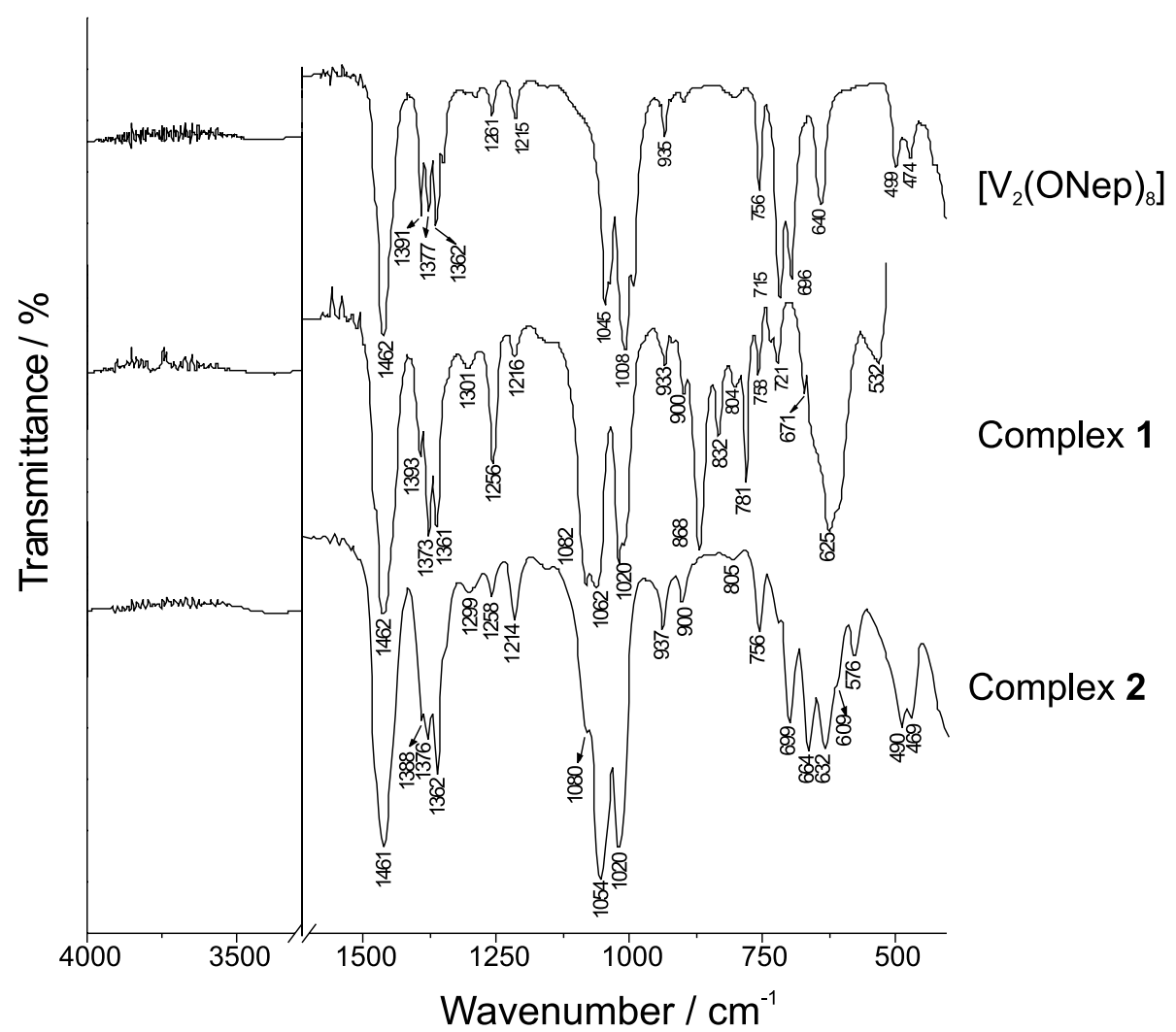

Figure S2. FTIR spectra (Nujol mull) of the $\left[\mathrm{V}_{2}(\mu-\mathrm{ONep})_{2}(\mathrm{ONep})_{6}\right]$ starting material and of the heterometal alkoxides $\mathbf{1}$ and 2. 
Table S1. Molecular dimensions for $\left[\mathrm{V}_{6} \mathrm{Li}_{10} \mathrm{O}_{8}(\mathrm{ONep})_{14}\left\{\mathrm{OSi}(\mathrm{Me})_{2}(\mathrm{ONep})\right\}_{2}\right] \cdot \mathrm{C}_{6} \mathrm{H}_{14}(\mathbf{1})$. Bond lengths are in Ångstroms, angles in degrees. Standard deviations are in parentheses

\begin{tabular}{|c|c|c|c|}
\hline \multicolumn{4}{|c|}{ (a) About the vanadium atoms } \\
\hline $\mathrm{V}(1) \ldots \mathrm{V}(2)$ & $2.8430(13)$ & $\mathrm{V}(2) \ldots \mathrm{V}(3)$ & $2.8998(13)$ \\
\hline $\mathrm{V}(1) \ldots \mathrm{V}(3)$ & $2.9075(13)$ & $\operatorname{Li}(1) \ldots V(3)$ & $2.896(10)$ \\
\hline $\mathrm{V}(1) \ldots \operatorname{Li}(1)$ & $2.850(10)$ & $\operatorname{Li}(2) \ldots V(3)$ & 2.991(10) \\
\hline $\mathrm{V}(1) \ldots \operatorname{Li}(4)$ & $2.739(9)$ & $\operatorname{Li}(3) \ldots V(3)$ & $2.875(9)$ \\
\hline $\operatorname{Li}(2) \ldots V(2)$ & $2.847(11)$ & $\operatorname{Li}(4) \ldots V\left(3^{\prime}\right)$ & $3.020(9)$ \\
\hline $\operatorname{Li}(5) \ldots V(2)$ & $2.761(9)$ & $\operatorname{Li}(5) \ldots V\left(3^{\prime}\right)$ & $3.055(9)$ \\
\hline $\mathrm{O}(13)-\mathrm{V}(2)-\mathrm{O}(15)$ & $84.51(15)$ & $\mathrm{O}(23)-\mathrm{V}(2)-\mathrm{O}(21)$ & $104.97(16)$ \\
\hline $\mathrm{O}(13)-\mathrm{V}(2)-\mathrm{O}(21)$ & $88.22(16)$ & $\mathrm{O}(22)-\mathrm{V}(2)-\mathrm{O}(15)$ & $81.86(15)$ \\
\hline $\mathrm{O}(13)-\mathrm{V}(2)-\mathrm{O}(22)$ & $130.31(15)$ & $\mathrm{O}(23)-\mathrm{V}(2)-\mathrm{O}(15)$ & $89.36(15)$ \\
\hline $\mathrm{O}(23)-\mathrm{V}(2)-\mathrm{O}(13)$ & $109.32(15)$ & $\mathrm{O}(21)-\mathrm{V}(2)-\mathrm{O}(22)$ & $93.37(15)$ \\
\hline $\mathrm{O}(21)-\mathrm{V}(2)-\mathrm{O}(15)$ & $165.44(14)$ & $\mathrm{O}(23)-\mathrm{V}(2)-\mathrm{O}(22)$ & $118.02(16)$ \\
\hline \multicolumn{4}{|c|}{ (b) About the lithium atoms } \\
\hline $\operatorname{Li}(1) \ldots \operatorname{Li}(2)$ & $2.569(15)$ & $\operatorname{Li}(2) \ldots \operatorname{Li}(3)$ & $2.797(15)$ \\
\hline $\operatorname{Li}(1) \ldots \operatorname{Li}(3)$ & $2.682(13)$ & $\mathrm{Li}(4)-\mathrm{O}(11)$ & $1.902(10)$ \\
\hline $\mathrm{Li}(2)-\mathrm{O}(15)$ & $1.931(11)$ & $\mathrm{Li}(4)-\mathrm{O}(13)$ & $2.034(10)$ \\
\hline $\mathrm{Li}(2)-\mathrm{O}(22)$ & $1.940(12)$ & $\mathrm{Li}(4)-\mathrm{O}\left(23^{\prime}\right)$ & $1.993(9)$ \\
\hline $\mathrm{Li}(2)-\mathrm{O}(33)$ & $2.418(11)$ & $\mathrm{Li}(4)-\mathrm{O}\left(32^{\prime}\right)$ & $2.056(10)$ \\
\hline $\mathrm{Li}(2)-\mathrm{O}(44)$ & $1.899(12)$ & $\operatorname{Li}(4) \ldots \operatorname{Li}(5)$ & $2.628(13)$ \\
\hline $\mathrm{O}(15)-\mathrm{Li}(2)-\mathrm{O}(22)$ & $83.4(5)$ & $\mathrm{O}(11)-\mathrm{Li}(4)-\mathrm{O}(13)$ & $83.3(4)$ \\
\hline $\mathrm{O}(15)-\mathrm{Li}(2)-\mathrm{O}(33)$ & $80.0(4)$ & $\mathrm{O}(11)-\mathrm{Li}(4)-\mathrm{O}\left(23^{\prime}\right)$ & $113.6(5)$ \\
\hline $\mathrm{O}(44)-\mathrm{Li}(2)-\mathrm{O}(15)$ & $98.6(5)$ & $\mathrm{O}(11)-\mathrm{Li}(4)-\mathrm{O}\left(32^{\prime}\right)$ & $156.3(5)$ \\
\hline $\mathrm{O}(22)-\mathrm{Li}(2)-\mathrm{O}(33)$ & $112.8(5)$ & $\mathrm{O}\left(23^{\prime}\right)-\mathrm{Li}(4)-\mathrm{O}(13)$ & $122.8(4)$ \\
\hline $\mathrm{O}(44)-\mathrm{Li}(2)-\mathrm{O}(22)$ & $158.0(6)$ & $\mathrm{O}(13)-\mathrm{Li}(4)-\mathrm{O}\left(32^{\prime}\right)$ & $97.4(4)$ \\
\hline $\mathrm{O}(44)-\mathrm{Li}(2)-\mathrm{O}(33)$ & $89.0(4)$ & $\mathrm{O}\left(23^{\prime}\right)-\mathrm{Li}(4)-\mathrm{O}\left(32^{\prime}\right)$ & $86.1(4)$ \\
\hline \multicolumn{4}{|l|}{ (c) In the ligands } \\
\hline $\mathrm{Si}(4)-\mathrm{C}(42)$ & $1.843(6)$ & $\mathrm{Si}(4)-\mathrm{C}(43)$ & $1.866(6)$ \\
\hline $\mathrm{Li}(4)-\mathrm{O}(11)-\mathrm{V}(1)$ & $91.6(3)$ & $\mathrm{V}(3)-\mathrm{O}(33)-\mathrm{Li}(2)$ & $86.0(3)$ \\
\hline $\mathrm{Li}(1)-\mathrm{O}(12)-\mathrm{V}(1)$ & $96.6(3)$ & $\mathrm{Li}(3)-\mathrm{O}(33)-\mathrm{V}(3)$ & $96.5(3)$ \\
\hline $\mathrm{V}(1)-\mathrm{O}(14)-\mathrm{V}(3)$ & $97.09(15)$ & $\mathrm{Li}(3)-\mathrm{O}(33)-\mathrm{Li}(2)$ & 79.4(4) \\
\hline $\mathrm{V}(1)-\mathrm{O}(14)-\mathrm{Li}\left(5^{\prime}\right)$ & $150.6(3)$ & $\mathrm{O}(41)-\mathrm{Si}(4)-\mathrm{C}(42)$ & 109.1(2) \\
\hline $\mathrm{Li}\left(5^{\prime}\right)-\mathrm{O}(14)-\mathrm{V}(3)$ & $93.5(3)$ & $\mathrm{O}(41)-\mathrm{Si}(4)-\mathrm{C}(43)$ & $108.8(3)$ \\
\hline $\mathrm{V}(2)-\mathrm{O}(21)-\mathrm{Li}(5)$ & $92.8(3)$ & $\mathrm{O}(44)-\mathrm{Si}(4)-\mathrm{O}(41)$ & $101.35(19)$ \\
\hline $\mathrm{V}(2)-\mathrm{O}(22)-\mathrm{Li}(2)$ & $94.9(3)$ & $\mathrm{C}(42)-\mathrm{Si}(4)-\mathrm{C}(43)$ & 107.7(3) \\
\hline $\mathrm{V}(2)-\mathrm{O}(23)-\mathrm{V}(3)$ & $97.66(15)$ & $\mathrm{O}(44)-\mathrm{Si}(4)-\mathrm{C}(42)$ & $114.8(2)$ \\
\hline $\mathrm{V}(2)-\mathrm{O}(23)-\mathrm{Li}\left(4^{\prime}\right)$ & $146.0(3)$ & $\mathrm{O}(44)-\mathrm{Si}(4)-\mathrm{C}(43)$ & $114.8(3)$ \\
\hline $\mathrm{Li}\left(4^{\prime}\right)-\mathrm{O}(23)-\mathrm{V}(3)$ & $93.5(3)$ & $\mathrm{Li}(2)-\mathrm{O}(44)-\mathrm{Li}(1)$ & $83.8(5)$ \\
\hline $\mathrm{V}(3)-\mathrm{O}(31)-\mathrm{Li}(1)$ & $89.3(3)$ & $\mathrm{Li}(1)-\mathrm{O}(44)-\mathrm{Li}(3)$ & $84.6(4)$ \\
\hline $\mathrm{Li}(3)-\mathrm{O}(31)-\mathrm{V}(3)$ & $94.3(3)$ & $\mathrm{Si}(4)-\mathrm{O}(41)-\mathrm{Li}(3)$ & $88.7(3)$ \\
\hline $\mathrm{Li}(3)-\mathrm{O}(31)-\mathrm{Li}(1)$ & $82.0(4)$ & $\mathrm{Si}(4)-\mathrm{O}(44)-\operatorname{Li}(1)$ & $133.7(4)$ \\
\hline $\mathrm{V}(3)-\mathrm{O}(32)-\mathrm{Li}\left(4^{\prime}\right)$ & $96.3(3)$ & $\mathrm{Li}(2)-\mathrm{O}(44)-\mathrm{Li}(3)$ & $90.6(4)$ \\
\hline $\mathrm{V}(3)-\mathrm{O}(32)-\mathrm{Li}\left(5^{\prime}\right)$ & $99.3(3)$ & $\mathrm{Si}(4)-\mathrm{O}(44)-\mathrm{Li}(2)$ & $142.3(4)$ \\
\hline $\mathrm{Li}\left(5^{\prime}\right)-\mathrm{O}(32)-\mathrm{Li}\left(4^{\prime}\right)$ & $80.5(4)$ & $\mathrm{Si}(4)-\mathrm{O}(44)-\mathrm{Li}(3)$ & $96.1(3)$ \\
\hline
\end{tabular}

Symmetry transformations used to generate equivalent atoms: ' : 1-x, 1-y, 1-z 
Table S2. Selected molecular dimensions for one of the two independent $\left[\mathrm{V}(\mathrm{ONep})_{3}(\mu-\mathrm{ONep})_{2} \mathrm{Li}(\mathrm{thf})_{2}\right]$ molecules in the crystals of complex 2. Bond lengths are in Ångstroms, angles in degrees. Standard deviations are in parentheses

\begin{tabular}{lccc}
\hline \multicolumn{1}{l}{ Bond lengths involving the vanadium and lithium atoms } & & \\
\hline $\mathrm{V}(4)-\mathrm{O}(41)$ & $1.932(3)$ & $\mathrm{V}(4)-\mathrm{O}(44)$ & $1.810(8)$ \\
$\mathrm{V}(4)-\mathrm{O}(42)$ & $1.863(3)$ & $\mathrm{V}(4)-\mathrm{O}(45)$ & $1.70(2)$ \\
$\mathrm{V}(4)-\mathrm{O}(43)$ & $1.863(3)$ & $\mathrm{V}(4) \ldots \mathrm{Li}(4)$ & $2.882(9)$ \\
$\mathrm{Li}(4)-\mathrm{O}(41)$ & $1.900(9)$ & $\mathrm{Li}(4)-\mathrm{O}(46)$ & $1.962(10)$ \\
$\mathrm{Li}(4)-\mathrm{O}(43)$ & $1.935(9)$ & $\mathrm{Li}(4)-\mathrm{O}(47)$ & $1.965(10)$ \\
\hline $\mathrm{Bond}$ angles about the vanadium and lithium atoms & & $95.7(2)$ \\
\hline $\mathrm{O}(42)-\mathrm{V}(4)-\mathrm{O}(41)$ & $170.77(16)$ & $\mathrm{O}(44)-\mathrm{V}(4)-\mathrm{O}(42)$ & $87.5(5)$ \\
$\mathrm{O}(43)-\mathrm{V}(4)-\mathrm{O}(41)$ & $\mathrm{O}(45)-\mathrm{V}(4)-\mathrm{O}(42)$ & $108.9(4)$ \\
$\mathrm{O}(44)-\mathrm{V}(4)-\mathrm{O}(41)$ & $\mathrm{O}(44)-\mathrm{V}(4)-\mathrm{O}(43)$ & $128.3(5)$ \\
$\mathrm{O}(45)-\mathrm{V}(4)-\mathrm{O}(41)$ & $\mathrm{O}(45)-\mathrm{V}(4)-\mathrm{O}(43)$ & $122.7(6)$ \\
$\mathrm{O}(42)-\mathrm{V}(4)-\mathrm{O}(43)$ & $\mathrm{O}(45)-\mathrm{V}(4)-\mathrm{O}(44)$ & $111.2(5)$ \\
$\mathrm{O}(41)-\mathrm{Li}(4)-\mathrm{O}(43)$ & $83.10(14)$ & $\mathrm{O}(43)-\mathrm{Li}(4)-\mathrm{O}(47)$ & $105.6(4)$ \\
$\mathrm{O}(41)-\mathrm{Li}(4)-\mathrm{O}(46)$ & $\mathrm{O}(46)-\mathrm{Li}(4)-\mathrm{O}(47)$ & $97.5(3)$ \\
$\mathrm{O}(41)-\mathrm{Li}(4)-\mathrm{O}(47)$ & $89.46(14)$ & $\mathrm{Li}(4)-\mathrm{O}(41)-\mathrm{V}(4)$ & $98.7(3)$ \\
$\mathrm{O}(43)-\mathrm{Li}(4)-\mathrm{O}(46)$ & $81.1(4)$ & $\mathrm{V}(4)-\mathrm{O}(43)-\mathrm{Li}(4)$ & \\
\hline
\end{tabular}

Additional notes on the solid state structure of $\left[\mathrm{V}(\mathrm{ONep})_{3}\right.$ $(\mu \text {-ONep })_{2}$ Li(thf) $\left.{ }_{2}\right] \cdot \mathrm{NepOH}($ Complex 2)

There are two independent V-Li complex molecules and two solvent (neopentanol) molecules in the crystal. One of the complex molecules shows disorder in three of its ligands, viz the $\mathrm{NpO}$ ligands of $\mathrm{O}(44)$ and $\mathrm{O}(45)$, and the thf ligand of $\mathrm{O}(46)$; these have all been resolved. In the thf ligand, one methylene group is disordered over two sites, giving alternative 'flaps' to the envelope conformations of this ligand. There are two distinct arrangements of the ligand of $\mathrm{O}(44)$, shown coordinated to $\mathrm{V}(4)$ through $\mathrm{O}(44)$ and $\mathrm{O}(44 \mathrm{~A})$; the central carbon atom of each, $\mathrm{C}(442)$ and $\mathrm{C}(44 \mathrm{~B})$, is common to both orientations and has been refined with coordinates and thermal parameters tied for the two atoms. The ONp ligand of $\mathrm{O}(45)$ is similar except that three orientations have been resolved for this ligand; the central atoms of all three, C(452), C(45B) and C(45Z), share common coordinates and thermal parameters; the
$\mathrm{O}$ atoms, $\mathrm{O}(45 \mathrm{~A})$ and $\mathrm{O}(45 \mathrm{X})$, of two of the ligands also share sites, and the methyl group carbon atoms $\mathrm{C}(455)$ and $\mathrm{C}(45 \mathrm{D})$, of the ligands of $\mathrm{O}(45)$ and $\mathrm{O}(45 \mathrm{~A})$, are shared by the third ligand, of $\mathrm{O}(45 \mathrm{X})$.

No hydroxyl hydrogen atoms have been located on any of the ONep ligands or discrete solvent molecules/anions. Considering vanadium(IV) and $\mathrm{Li}^{+}$in the complexes, to balance charges, the separate small ONep units must be neopentanol molecules, with hydroxyl $\mathrm{H}$ atoms that cannot be seen at the present resolution level. Assuming that the discrete molecules are $\mathrm{NepOH}$, there are suitable acceptor groups for hydrogen bond formation between $\mathrm{O}(18)-\mathrm{H}$ and $\mathrm{O}(15)$, and between $\mathrm{O}(48)-\mathrm{H}$ and either $\mathrm{O}(44 \mathrm{~A})$ or $\mathrm{O}(45)$; the $\mathrm{O} \cdots \mathrm{O}$ distances are 2.844, 2.986 and $3.007 \AA$ respectively, and the corresponding $\mathrm{C}-\mathrm{O} \cdots \mathrm{O}$ angles are 104.6, 109.2 and $86.0^{\circ}$ (Figure S1). The oxidation state $+\mathrm{IV}$ of the transition metal in $\mathbf{2}$ is further supported by the EPR studies described in the manuscript. 